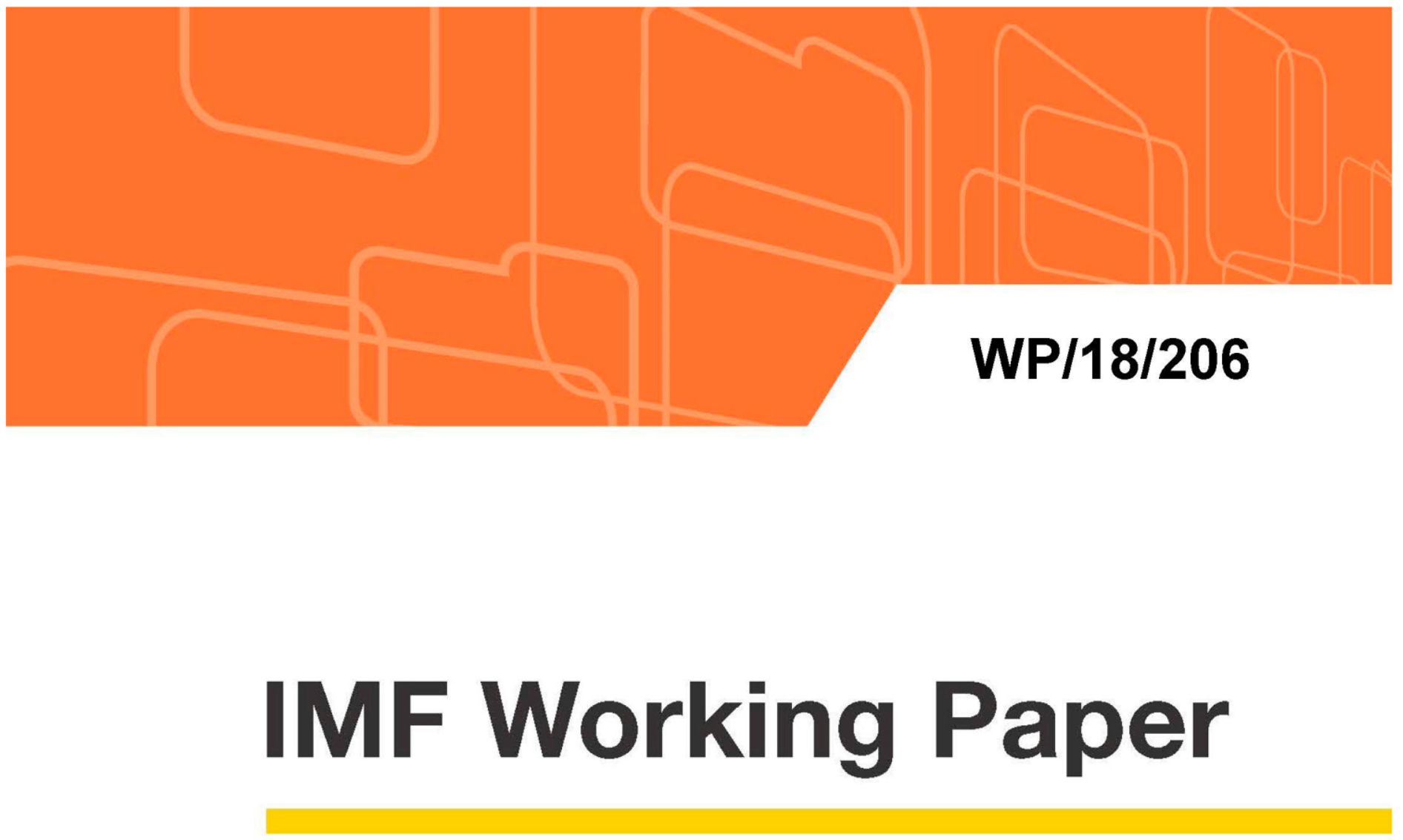

\title{
Systemic Banking Crises Revisited
}

by Luc Laeven and Fabian Valencia

IMF Working Papers describe research in progress by the author(s) and are published to elicit comments and to encourage debate. The views expressed in IMF Working Papers are those of the author(s) and do not necessarily represent the views of the IMF, its Executive Board, or IMF management. 


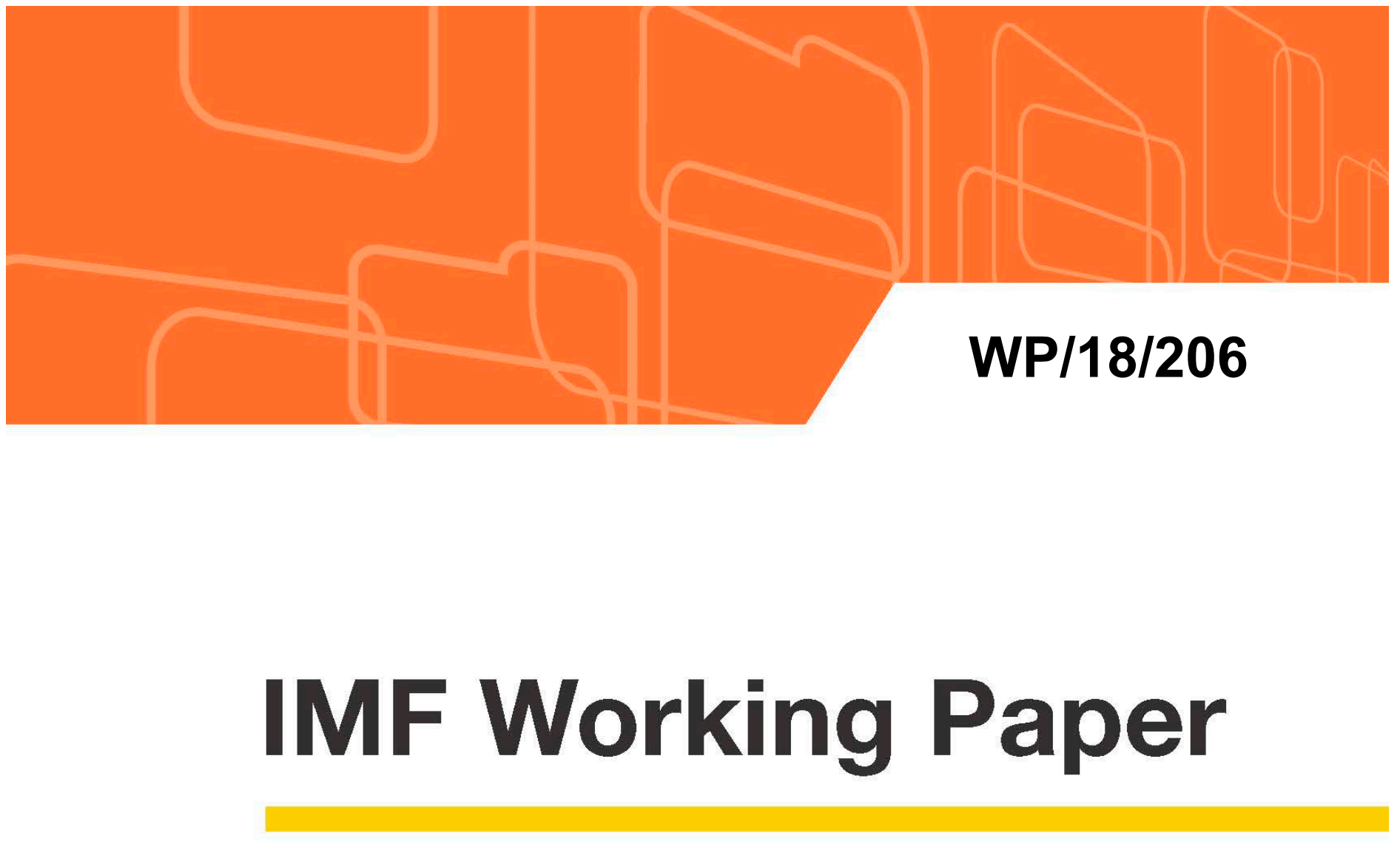

\section{Systemic Banking Crises Revisited}

by Luc Laeven and Fabian Valencia

IMF Working Papers describe research in progress by the author(s) and are published to elicit comments and to encourage debate. The views expressed in IMF Working Papers are those of the author(s) and do not necessarily represent the views of the IMF, its Executive Board, or IMF management.

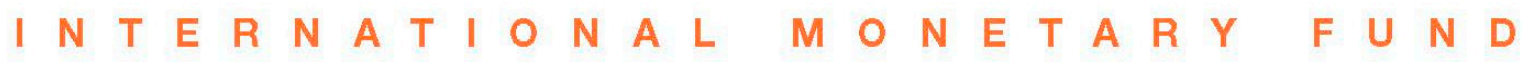




\title{
IMF Working Paper
}

Strategy, Policy, and Review Department

Systemic Banking Crises Revisited

\section{Prepared by Luc Laeven and Fabian Valencia ${ }^{1}$}

Authorized for distribution by Vikram Haksar

September 2018

\section{IMF Working Papers describe research in progress by the author(s) and are published to elicit comments and to encourage debate. The views expressed in IMF Working Papers are those of the author(s) and do not necessarily represent the views of the IMF, its Executive Board, or IMF management.}

\begin{abstract}
This paper updates the database on systemic banking crises presented in Laeven and Valencia (2008, 2013). Drawing on 151 systemic banking crises episodes around the globe during 1970-2017, the database includes information on crisis dates, policy responses to resolve banking crises, and the fiscal and output costs of crises. We provide new evidence that crises in high-income countries tend to last longer and be associated with higher output losses, lower fiscal costs, and more extensive use of bank guarantees and expansionary macro policies than crises in low- and middle-income countries. We complement the banking crises dates with sovereign debt and currency crises dates to find that sovereign debt and currency crises tend to coincide or follow banking crises.
\end{abstract}

JEL Classification Numbers: E50; E60; G20.

Keywords: banking crisis; financial crisis; bank restructuring; crisis resolution.

Author's E-Mail Address: Luc.Laeven@ecb.europa.eu and Fvalencia@,imf.org.

\footnotetext{
${ }^{1}$ Luc Laeven is Director-General of the Directorate General Research at the European Central Bank and Fabian Valencia is Deputy Chief in the Macrofinancial Analysis Unit in the Strategy, Policy and Review Department at the IMF. The authors thank Sergei Antoshin, Ashok Bhatia, Raymond Chaudron, Luis Cortavarria-Checkley, Ingimundur Friðriksson, Vikram Haksar, Samba Mbaye, Aiko Mineshima, Herimandimby Razafindramanana, Mohamed Sidi Bouna, and Jón P. Sigurgeirsson for insightful comments and Eugenia Menaguale for outstanding research assistance. The views expressed in this paper are those of the authors and do not reflect the views of the ECB, the ECB Executive Board, the IMF, the IMF Executive Board, or IMF Management.
} 


\section{Contents}

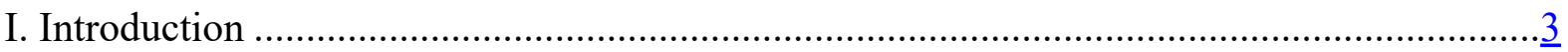

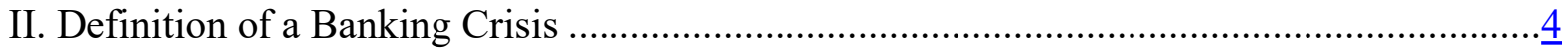

III. Banking Crises Episodes During 1970-2017 ........................................................

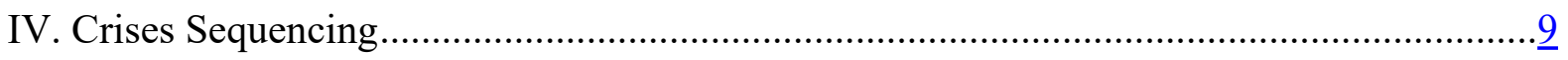

V. Policy Response to Banking Crises .......................................................................... 12

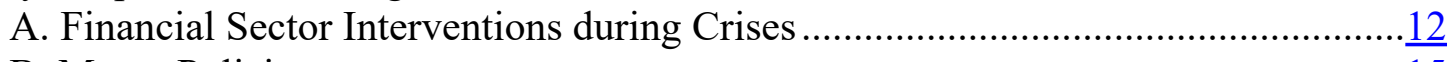

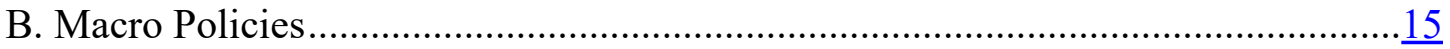

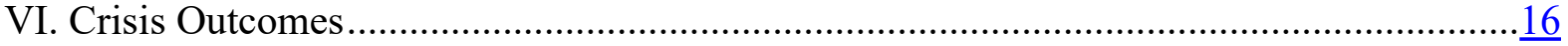

A. Fiscal Costs of Banking Crises .............................................................. $\frac{17}{20}$

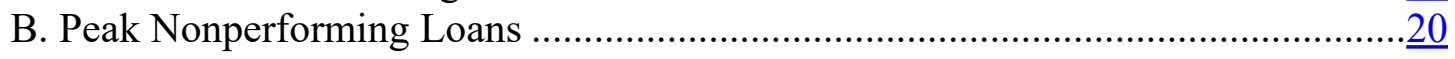

C. Systemic Banking Crisis Duration ........................................................

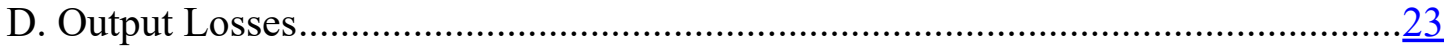

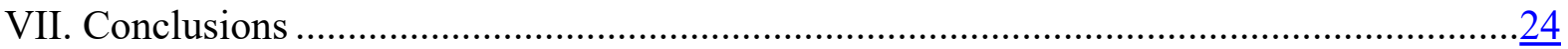

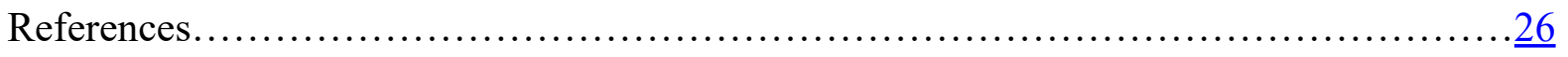

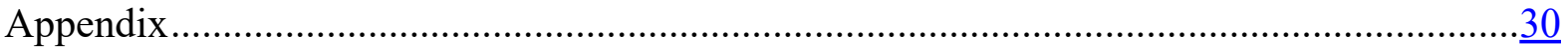

\section{Figures}

1. Frequency of Systemic Banking Crises Around the World, 1970-2011 ..........................

2. Systemic Banking Crises Episodes by Income Level 1970-2017 ...................................

3. Currency and Sovereign Debt Crises Episodes by Income level................................... 10

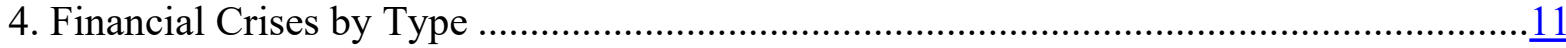

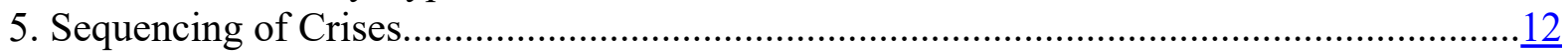

6. Containment and Resolution Policies ..................................................................... $\frac{15}{16}$

7. Short-term Interest Rates and Fiscal Balances around Banking Crises ........................... $\frac{16}{18}$

8. Gross and Net Fiscal Costs of Banking Crises ...................................................... 18

9. Fiscal Costs in Percent of Financial System Assets.....................................................19

10. Increases in Public Debt around Banking Crises ................................................... 20

11. Peak NPLs in Banking Crises Episodes.................................................................... $\frac{21}{22}$

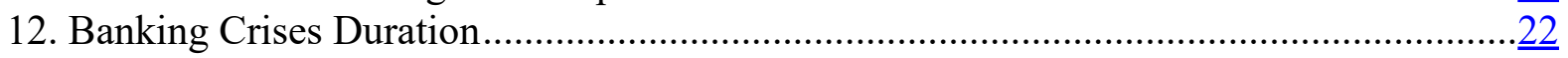

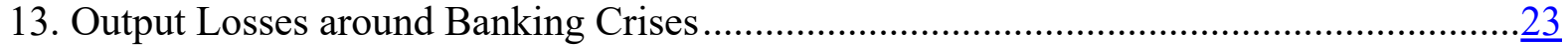

14. Output and Export Volume Paths around Banking Crises............................................24

\section{Appendix Tables}

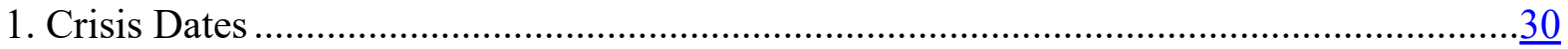

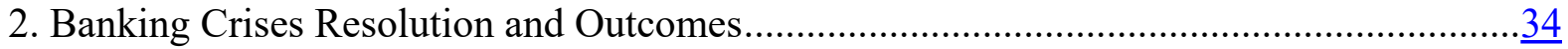

3. Banking Crisis Policy Responses.................................................................................. 


\section{INTRODUCTION}

Systemic banking crises are highly disruptive events which lead to sustained declines in economic activity, financial intermediation, and ultimately in welfare. It is then no surprise that academics and policymakers devote significant efforts to develop models to attempt to predict crises and to design policies to resolve them and mitigate their economic impacts. But much of these efforts crucially depend on the proper identification of the dates when these crises occur. The use of an inappropriate crisis dating measure may obscure a true relationship between a crisis event and other economic variables or create the appearance of a causal link when there is none.

To facilitate this endeavor, this paper updates the comprehensive global database on systemic banking crises in Laeven and Valencia (2008, 2013), which has become the standard reference for information on banking crises worldwide, to cover all episodes during the period 1970-2017. As in our previous versions of the database, we date systemic banking crises based on the intensity of the policy response to reduce the use of subjective criteria to identify crisis episodes. As in Laeven and Valencia (2013), the database on banking crises episodes during the period 1970-2017 is further complemented with dates of sovereign debt and currency crises during the same period. In total, we identify 151 banking crises, 236 currency crises, and 74 sovereign crises.

The database also includes information about policy responses, fiscal costs, output losses, and other stylized facts about banking crises. When comparing banking crises episodes across countries of different income levels, we find significant differences. In terms of policy responses, we find that the use of financial intervention policies in high-income countries tends to be similar to that in low and middle-income economies, except for guarantees on bank liabilities. The use of the latter has been relatively more common in high-income countries, arguably due to a higher quality of institutions and/or larger fiscal space which rendered the guarantees relatively more credible. Moreover, we document a more extensive use of expansionary monetary and fiscal policies in banking crises episodes in high-income economies than in low- and middle-income ones. Availability of fiscal and monetary space and/or ability to finance larger deficits allowed high-income countries to act countercyclically to mitigate the impact of the crisis on the real economy. In contrast, lowand middle-income countries may have faced binding borrowing constraints that forced them to act procyclically during crisis episodes.

We also find that direct fiscal costs of banking crises - defined as fiscal outlays directly related to government intervention measures in the financial sector-tend to be larger in lowand middle-income countries than in high-income countries. However, using a broader definition of fiscal costs that includes fiscal outlays not directly targeting the financial sector-measured as the increase in public debt-to-GDP ratios around banking crises - we find the exact opposite: increase in public indebtedness tend to be more pronounced for highincome countries. This result follows from a combination of a greater ability of high-income 
countries to use fiscal stimulus during banking crises, which increases public debt, and larger output losses in high-income countries in the aftermath of banking crises. ${ }^{2}$

The literature on banking crisis dating has attracted increased attention since the global financial crisis with notable contributions including Reinhart and Rogoff (2009), Schularick and Taylor (2012), Romer and Romer (2017), and Baron and others (2018). Several of these studies document similarities and differences in outcomes with our earlier versions of the database (Laeven and Valencia, 2008, 2013). Relative to these other papers, the main advantage of our database is the dating of banking crises for a comprehensive sample of countries and the documentation of policy responses during such crises. ${ }^{3}$ This distinction is important, particularly for drawing implications of banking crises beyond advanced economies and large emerging markets.

The remainder of the paper is organized as follows. Section II presents our definition of banking crises. Section III shows the resulting list of crises during the period 1970-2017. Section IV complements our banking crises dates with those for currency and sovereign debt crises. Section V presents the policy responses and Section VI presents the crisis outcomes, including fiscal costs and output losses. Section VII concludes.

\section{Definition of a Banking CRISIS}

We follow in this paper the same definition adopted in Laeven and Valencia (2013), reproduced below for convenience, where we define a banking crisis as an event that meets two conditions:

1) Significant signs of financial distress in the banking system (as indicated by significant bank runs, losses in the banking system, and/or bank liquidations).

2) Significant banking policy intervention measures in response to significant losses in the banking system.

We consider the first year that both criteria are met to be the year when the crisis became systemic. This is to ensure that we date the crisis at the first signs of major problems in the banking system.

When the losses in the banking sector and/or liquidations are severe, we treat the first criterion as a sufficient condition to date a systemic banking crisis. We operationalize this

\footnotetext{
${ }^{2}$ The studies by Schularick and Taylor (2012), Romer and Romer (2017), and Baron and others (2018) cover only a comparatively small number of countries.

${ }^{3}$ The studies by Schularick and Taylor (2012), Romer and Romer (2017), and Baron and others (2018) cover only a comparatively small number of countries.
} 
definition by considering that losses are severe when either (i) a country's banking system exhibits significant losses resulting in a share of nonperforming loans above 20 percent of total loans or bank closures of at least 20 percent of banking system assets or (ii) fiscal restructuring costs of the banking sector are sufficiently high, exceeding 5 percent of GDP. ${ }^{4}$ However, relying exclusively on the first criterion is problematic because it is not always straightforward to quantify the degree of financial distress in a banking system, particularly in low- and middle-income countries, and also because losses can be mitigated by policy responses. To address this problem, we also rely on the second criterion, if policy intervention meets the requirement of being significant. We consider policy interventions in the banking sector to be significant if at least three out of the following six measures have been used: ${ }^{5}$

1) deposit freezes and/or bank holidays;

2) significant bank nationalizations;

3) bank restructuring fiscal costs (at least 3 percent of GDP);

4) extensive liquidity support (at least 5 percent of deposits and liabilities to nonresidents);

5) significant guarantees put in place; and

6) significant asset purchases (at least 5 percent of GDP);

The above categories cover all policy interventions that have been employed to resolve a banking crisis (see Honohan and Laeven, 2005, and Laeven and Valencia, 2008). Since not all policies are used in all crises, we require that at least three measures have been put in place. It is worth noting that setting thresholds sufficiently high helps us avoid labeling a non-systemic event or the preemptive use of some of these policies as a systemic banking crisis. ${ }^{6}$ For interventions that can be quantified more easily, such as liquidity support, asset purchases, and financial restructuring costs, we also adopt quantitative thresholds to define what significant intervention means.

\footnotetext{
${ }^{4}$ Examples of such severity include Latvia's 1995 crisis, when banks totaling 40 percent of financial system's assets were closed; and more recently Moldova (2014) and Ukraine (2014).

${ }^{5}$ We express our measure of fiscal costs in terms of GDP. However, whenever available, we also report fiscal costs expressed in percent of financial system assets.

${ }^{6}$ Other researchers (e.g., Demirgüç-Kunt and Detragiache, 1998) have used milder thresholds resulting in more crisis episodes. However, milder thresholds tend to increase the proportion of non-systemic events in the sample, while our focus is on systemic crises.
} 
The policy variables we used in our crisis definition are more specifically defined as follows:

- Deposit freeze and bank holidays: indicates whether the government introduced restrictions on deposit withdrawals or a bank holiday. If implemented, we also collect information on the duration of the deposit freeze and bank holiday, and the affected instruments.

- Significant nationalizations: takeovers by the government of systemically important financial institutions, including cases where the government takes a majority stake in the capital of such financial institutions.

- Significant bank guarantees: a significant government guarantee on bank liabilities, indicating that either a full protection of liabilities has been issued by the government or that government guarantees have been extended to non-deposit liabilities of banks. ${ }^{7}$ Actions that only raise the level of deposit insurance coverage are not included. ${ }^{8}$

- Liquidity support: It is measured as central bank claims on other depository institutions (from IFS) and liquidity support directly provided by the Treasury. We normalize this variable by the total deposits and bank liabilities to non-residents. We consider liquidity support to be extensive when this ratio exceeds 5 percent and more than doubles relative to its pre-crisis level. ${ }^{9}$

- Bank restructuring costs: defined as gross fiscal outlays directed to the restructuring of the financial sector, with the most important component being recapitalization costs. We consider restructuring costs to be significant if they exceed 3 percent of GDP, excluding liquidity assistance provided directly from the treasury. We focus on gross fiscal costs instead of net because it takes time to record recoveries. However, wherever data on recoveries were available we report also net fiscal costs.

- Asset purchases: This variable refers to purchases of assets from financial institutions implemented by the central bank, the treasury, or a government entity (such as an asset management company). We define significant asset purchases as those exceeding 5 percent of GDP.

\footnotetext{
${ }^{7}$ Although we do not consider a quantitative threshold for this criterion, in all cases guarantees involved significant financial sector commitments relative to the size of the corresponding economies.

${ }^{8}$ Laeven and Valencia (2013) present also information on whether a previous explicit deposit insurance arrangement was in place at the time of the introduction of the blanket guarantee.

${ }^{9}$ This measure of liquidity would also capture the impact of currency swap lines among central banks, agreed during the global financial crisis, to the extent that they were used to inject liquidity in the financial sector.
} 
Figure 1. Frequency of Systemic Banking Crises Around the World, 1970-2017

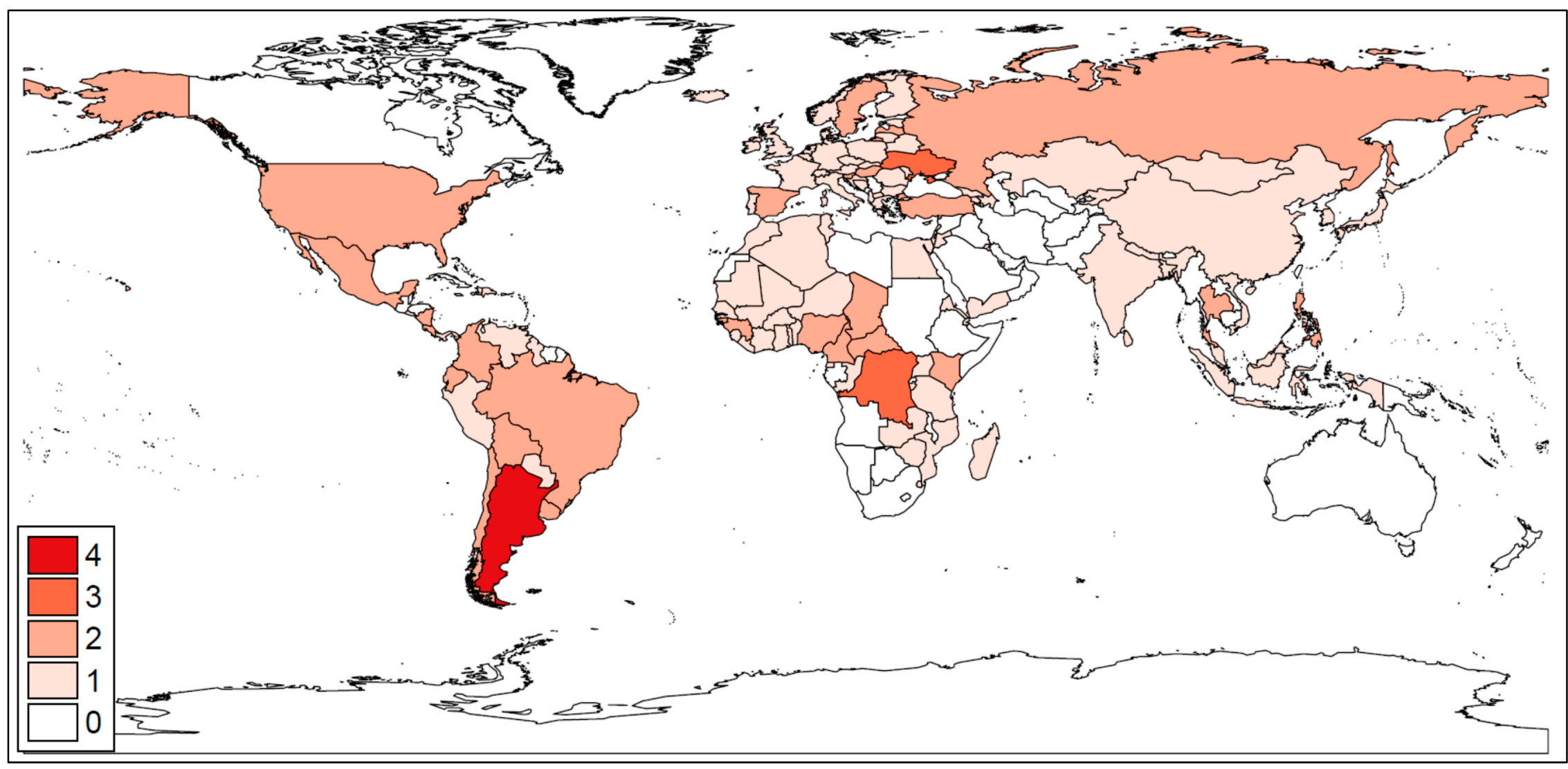

Source: Authors' calculations. 
The logic for choosing this approach to date banking crises is to reduce the use of subjective criteria in identifying these events, which gives our database a clear advantage over existing databases such as Caprio and Klingebiel (1996) and Reinhart and Rogoff (2009). Moreover, the chosen thresholds for policy intervention help us focus only on systemic events, where subjectivity in the identification of crises is further reduced. And finally, it is a relatively simple definition that allows a consistent implementation across time periods and countries of different income levels. In Laeven and Valencia (2013) we showed that many episodes in our dataset can be replicated by a simple alternative definition based on credit and real GDP growth, particularly in high-income countries.

More recent studies have explored alternative crisis dating strategies, such as Romer and Romer (2017), who rely on a narrative approach to identify episodes of financial distress in 24 OECD countries; Baron and others (2018), who identify crises in 46 countries by looking at large declines in banks' stock prices; and Chaudron and de Haan (2014), who study four crises for which the timing strongly differs across databases. Chaudron and de Haan (2014) conclude that using information on the number and size of bank failures allows determining the timing of banking crises more precisely. Their dating for these four episodes corresponds closely with ours. More generally, all these studies note important similarities with our crisis dating to the extent that the samples overlap. However, our approach allows a more comprehensive coverage of countries.

\section{BANKING CRISES EPISODES DURING 1970-2017}

Our definition identifies 151 banking crises since 1970, of which 4 episodes started since 2011: Cyprus (2011), Guinea Bissau (2014), Moldova (2014), and Ukraine (2014). The complete dataset is included in the accompanying data file with the main variables reported in the appendix. The banking crises dates-years for all cases, and year and month whenever feasible - include borderline systemic crises, defined as cases where our definition is close to being met. Most countries have experienced at least one systemic banking crisis during 1970-2017, with many going through multiple episodes (Figure 1). However, only three countries experienced more than two systemic banking crises during the past 48 years: Argentina (4), the Democratic Republic of Congo (3), and Ukraine (3).

Following the World Bank's historical income classification, we group episodes according to the income level of the affected country at the start of the crisis (Figure 2). Figure 2 shows that systemic banking crises are rarely single-country events, with waves of crises clearly visible in the figure, starting with the episodes in Latin America in the early 1980s, the crises in the aftermath of the breakup of the Soviet Union, the Tequila Crisis, the Asian crisis, and more recently the global financial crisis. The period around the mid-2000s was unusual in terms of the low incidence of crises, which was disrupted by the global financial crisis. Since then, some episodes have taken place in low- and middle-income countries, but in general we are facing again a period of relative calm in what pertains to systemic banking crises. The figure also shows that the late eighties and nineties included some episodes in high-income 
countries, reflecting the savings and loans crisis in the United States, the crises in the Nordic countries in the early 1990s, and the one in Japan in the late 1990s. However, prior to the 2008 global financial crises, banking crises had predominantly been a low and middleincome country phenomenon, at least since 1970. As noted by Reinhart and Rogoff (2009), the global financial crisis made it clear that "financial crises are an equal opportunity menace" for high-and low and middle-income countries.

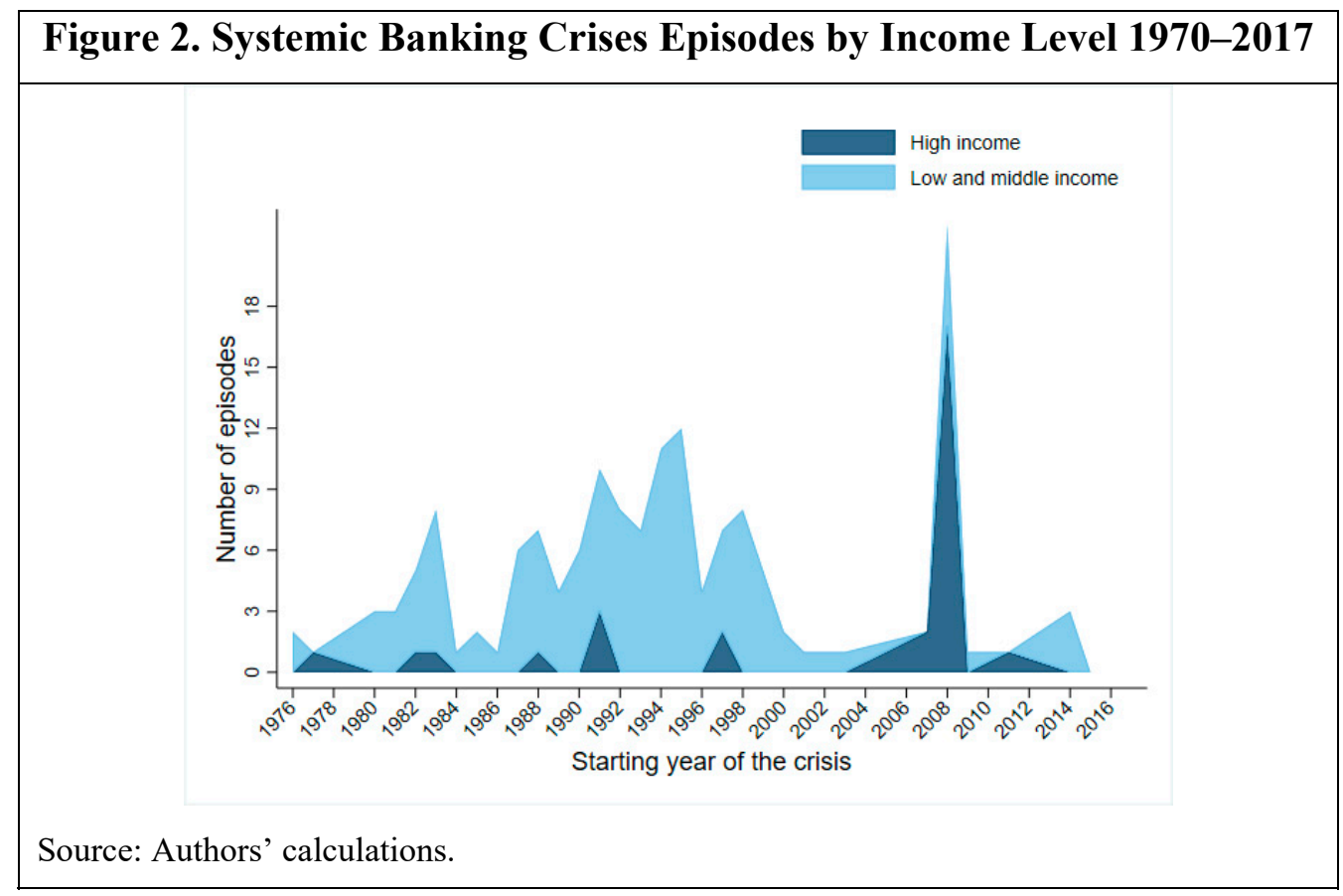

\section{Crises Sequencing}

To assess the sequencing of crisis, we complement the database with currency and sovereign crises dates. We follow the same definitions employed in Laeven and Valencia $(2008,2013)$, which in turn build on Frankel and Rose's (1996) approach. We define a currency crisis as a "sharp" nominal depreciation of the currency vis-a-vis the U.S. dollar. We consider two thresholds for a depreciation to meet this definition: i) a year-on-year depreciation of at least 30 percent; and ii) of at least 10 percentage points higher than the rate of depreciation observed in the year before. ${ }^{10}$ Under this definition, there were 236 currency crises during the period 1970-2017. ${ }^{11}$ We choose bilateral exchange rates because we are interested in the loss

\footnotetext{
${ }^{10}$ We use end-of-period official nominal bilateral exchange rates from the IMF's World Economic Outlook (WEO) database. For countries that meet the currency crisis criteria for several continuous years, we use the first year of each five-year window to identify the crisis. While our approach resembles that of Frankel and Rose (1996), our thresholds are not identical to theirs.

${ }^{11}$ As in Laeven and Valencia (2013), we exclude from the list currency crises that occur in countries that were early in the process of transition toward market economies.
} 
of value relative to a reserve currency. Admittedly, the identified episodes can vary with the thresholds, as noted in Laeven and Valencia (2013). However, it is a simple definition that can be implemented easily across countries.

We also date episodes of sovereign debt default and restructuring by relying on information from Beim and Calomiris (2001), World Bank (2002), Sturzenegger and Zettelmeyer (2006), IMF Staff reports, and reports from rating agencies and the media. The compiled data on sovereign debt crises reported in our database include the year of sovereign default to private creditors and/or restructuring. If public debt was restructured without a suspension of payments, the sovereign crisis year is recorded as the year of the restructuring. Using this approach, we identify 75 episodes of sovereign debt crises during 1970-2017, 11 of which took place since 2007. Figure 3 shows the frequency of currency and sovereign debt crises episodes by year and income level.

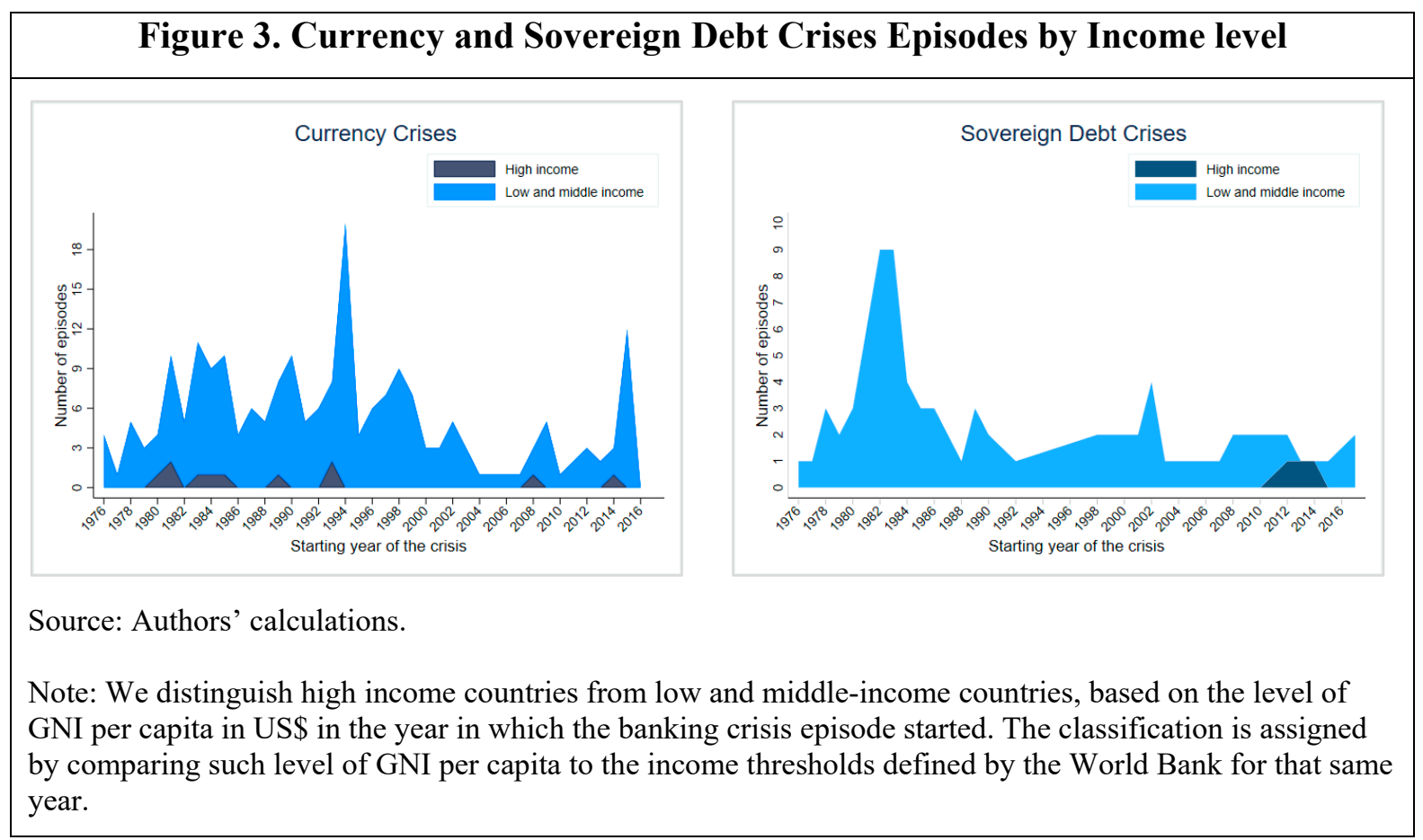

Currency crises are a rare phenomenon among high-income countries, including during the global financial crisis, in part due to the reserve currency status of some of these economies. The global financial crisis brought about sovereign debt crises in high-income countries: Greece with its 2012 restructuring and the 2015 default to the IMF, and Cyprus with the 2013 debt exchange.

Banking and sovereign debt crises can coincide, either because the entire economy is hit by a large shock, or because there are sizeable spillovers from the public to the banking sector (i.e., through banks' sovereign exposures) or from the banking to the public sector (i.e. through sovereign bailouts of banks) (IMF, 2015; Dell'Ariccia and others, 2018). And analogous connections can be drawn between banking and currency crises: for instance, 
when a sharp depreciation of the currency wipes out banks' capital due to large open foreign exchange positions of their own or their borrowers or when significant bank failures lead depositors to seek shelter in foreign assets, simultaneously provoking a run on the currency.

Figure 4 shows the incidence of banking, currency, and sovereign debt crises over the sample period covered in our database. We find that all three types of crises, not just banking crises, come in waves. The number of sovereign debt crises peaked in the mid-1980s, driven predominantly by Latin America, with recent episodes including both high and low and middle-income economies. The frequency of currency crises peaked in the mid-1990s and saw surges around the global financial crisis. Their incidence increased in 2015 due to the large currency depreciations in many commodity-exporter countries triggered by a decline in commodity prices (Kohlscheen and others, 2017). The figure also reports the number of standalone crises as well as those that coincided with other types of crises. ${ }^{12}$ In total we document 11 triple crises (i.e., simultaneous banking, currency, and sovereign debt crises in a given country) over the period 1970-2017. Among twin crises, the currency/banking and currency/debt crisis pairs tend to be more common than the banking/debt crisis pair.

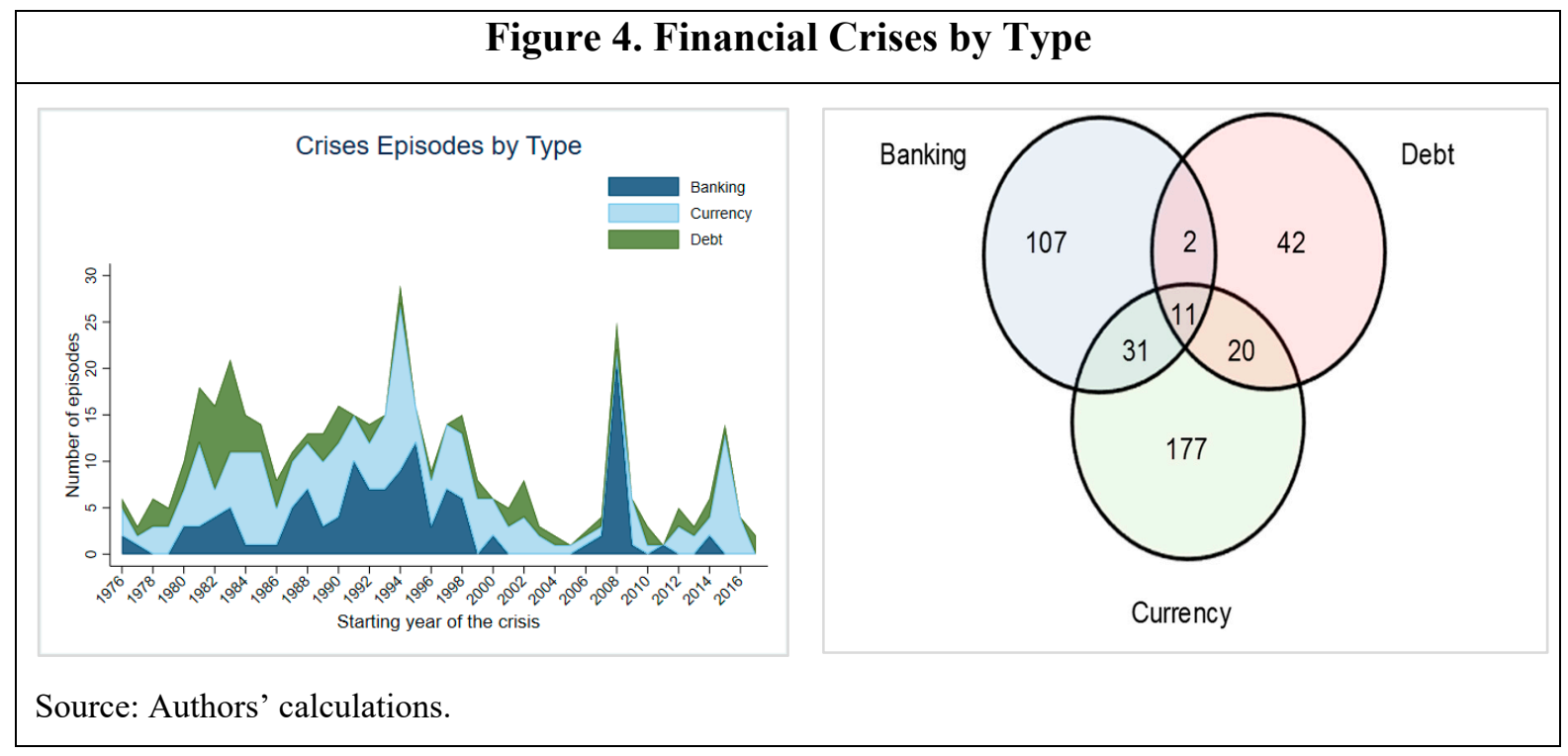

To better identify a crisis sequencing pattern, we show in Figure 5 the incidence of currency and sovereign debt crises along a time scale (in years) in countries that experienced a banking crisis in year T. A clearer pattern now emerges. Currency and sovereign debt crises, on average, tend to coincide or follow banking crises, with currency crises peaking at one year after the beginning of the banking crisis. This pattern is in line with findings in earlier

\footnotetext{
${ }^{12}$ We define a twin crisis in year $\mathrm{T}$ as a banking crisis in year $\mathrm{t}$, combined with a currency (sovereign debt) crisis during the period [T-1, $\mathrm{T}+1]$, and we define a triple crisis in year $\mathrm{T}$ as a banking crisis in year $\mathrm{T}$, combined with a currency crisis during the period $[\mathrm{T}-1, \mathrm{~T}+1]$ and a sovereign debt crisis during the period $[\mathrm{T}-1$, $\mathrm{T}+1$ ]. Identifying the overlap between banking (currency) and sovereign crises follows the same approach, with $\mathrm{T}$ the year of a banking (currency) crisis.
} 
studies that have examined the causes as well as the sequencing of crises (e.g., Kaminsky and Reinhart, 1999; Fratzscher and others, 2011; Reinhart and Rogoff, 2011; Gourinchas and Obstfeld, 2012). Although they covered different sample periods and relied on different definitions of crises, the similarity in the conclusion is quite clear: it is common for banking crises to happen at the same time or precede currency and sovereign debt crises. This provides a clear rationale for our emphasis on banking crises.

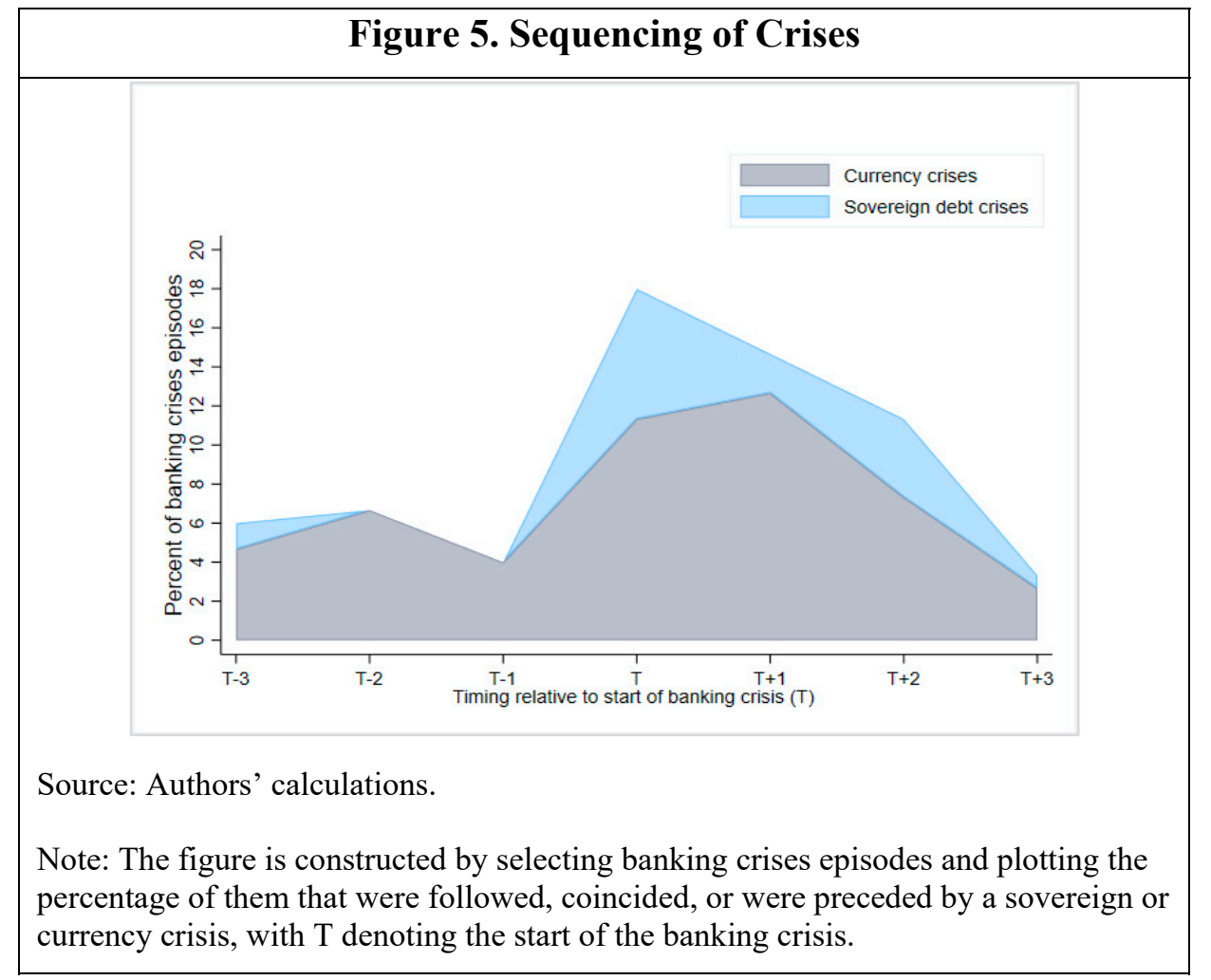

\section{Policy Response to Banking CRises}

To complement our crisis dating database, we collect information on policy responses deployed during these episodes and directed towards containing and/or resolving a banking crisis. While our focus is predominantly on financial sector policy interventions, we also look at crude measures of monetary and fiscal policy to offer a broad perspective on policy responses during banking crises.

\section{A. Financial Sector Interventions during Crises}

Initially, a country's policy response to bank distress typically includes the deployment of liquidity support to the banking sector, particularly in response to bank runs. The provision of extensive liquidity support during systemic banking crises is pervasive in our sample. We measure liquidity support as the ratio of central bank claims on the financial sector to 
deposits and foreign liabilities. ${ }^{13}$ We report two measures of liquidity support: the peak of this ratio, labeled as peak liquidity support in Table 2 in the appendix, and the change between the peak and the average of the ratio during the year before the start of the crisis, labeled as liquidity support. The median peak liquidity support ratio reaches 20.2 percent, with 100 out of 151 episodes recording a positive value of up to 28 percent. However, the median peak liquidity at 12 percent for high-income countries is less than half of the 23 percent recorded for low-and middle-income countries. The second measure, liquidity support, shows up with a median of 10.8 percent, with 95 out of 151 episodes exhibiting a positive value of up to 16 percent. Again, the median value for high-income countries, at 6.4 percent, is less than half of the 14.8 percent corresponding to low and middle-income countries.

While both high and low and middle-income countries have relied extensively on liquidity support when hit by a crisis, Laeven and Valencia (2010), Claessens and others (2011), and Stone and others (2011), have noted the wider array of instruments used by high-income countries when experiencing a crisis, including through the coordinated deployment of central bank swap facilities during the global financial crisis. These studies have also pointed out that low and middle-income countries tend to rely on liquidity provision as a containment tool for much longer than high-income countries, on average, before introducing bank recapitalization and restructuring measures. Weaker institutions, including non-independent central banks and regulators, in some low and middle-income countries particularly in the 1980s and 1990s, may have led to the prolonged reliance on liquidity support and a delayed recognition of bank solvency problems. Bank recapitalization measures, such as the Trouble Asset Relief Program (TARP) in the United States, were deployed much quicker during the global financial crises, compared to episodes prior to the global financial crisis (predominantly in low and middle-income countries). The more prolonged reliance on liquidity support in low and middle-income economies may explain why it tended to be higher in these episodes than in high-income countries.

During the early stages of banking crises, and often in combination with liquidity support, governments have also resorted to limited or full guarantees on some or most bank liabilities, to help stem bank runs and alleviate liquidity pressures on these entities. They typically buy policymakers time to develop more comprehensive resolution and restructuring plans. Laeven and Valencia (2012) examine the experience of 42 crisis episodes, of which 14 made use of explicit guarantees on bank liabilities and find that these guarantees do help to reduce liquidity pressures on banks. Altogether, we report in our database 34 crisis episodes where blanket guarantees were announced, of which 19 cases corresponded to high-income countries, mostly during the 2008 global financial crisis. Guarantees are often left in place for many years and are only gradually removed. The blanket guarantees announced in Mexico in

\footnotetext{
${ }^{13}$ We exclude domestic non-deposit liabilities from the denominator of this ratio because information on such liabilities is not readily available on a gross basis.
} 
1993 and in Malaysia in 1998 were fully removed only in 2003 and 2005, respectively. At end-2016, European Union governments collectively still had 120 billion euros in outstanding guarantees issued in support of the financial system, according to the European Commission's 2017 State Aid Scoreboard. While this amount represents a sharp decline from its peak of 835 billion euros in 2009, it remains non-trivial.

In cases where liquidity pressures have been significant, countries have in some cases resorted to administrative measures, suspending the convertibility of deposits into cash and restricting foreign payments. These "deposit freezes" have often been preceded by bank holidays - the temporary closure of banks - often by design as banks need some time to adapt their IT systems and procedures to the new regime. However, bank holidays and deposit freezes have been rarely used. We report in our database only 8 episodes were deposit freezes were imposed. The most recent cases include Cyprus in 2013, Ukraine in 2014, and Greece in 2015. In Cyprus, restrictions to domestic payments were removed in May 2014, while those on external payments remained in place until April 2015. For Ukraine, cash withdrawals from domestic currency bank accounts were lifted in September 2016 and those from FX accounts in August 2017, although some restrictions on FX transactions remained in place as of early 2018. Similarly, in Greece, the restrictions on deposits have been gradually relaxed since their introduction in July 2015, but there were restrictions still in place as of early 2018 , including a monthly limit on cash withdrawals and limits on cross-border bank transfers.

We report 6 bank holidays, with Cyprus and Greece being the only recent cases. In 5 of the 6 cases, the bank holiday was in place for a length between 4 and 8 days. The exception is Greece where the bank holiday was in place for 21 days. In all the 6 reported instances, the bank holiday was followed by a deposit freeze.

The above policies are intended to contain liquidity pressures. However, banks experiencing significant drains in liquidity often see a deterioration in their capital position as they are forced into asset disposals at fire sale prices to meet liquidity needs. Compounded by a deterioration in asset quality as financially weakened borrowers fall delinquent on their loans, additional measures are often needed to restore solvency of affected banks. These may include private or public recapitalization of viable institutions, resolution of insolvent ones, and even outright nationalization. The appropriateness and effectiveness of these tools in situations of severe financial distress have been widely studied in the literature. There is theoretical research showing that in those circumstances recapitalizing banks with public money can increase welfare (e.g., Philippon and Schnabl, 2013; and Sandri and Valencia, 2013) and there is empirical evidence suggesting that recapitalizing banks with public money can alleviate the real effects of banking crises (e.g., Homar and others, 2017; Giannetti and Simonov, 2013; and Laeven and Valencia, 2013). Implementation, however, may take many forms (Laeven and Valencia, 2008; Claessens and others, 2014). 
Bank recapitalization is a tool that has been used in most crises we report in our database, and it is also the most important component of direct fiscal costs from government intervention in the financial sector. Government capital injections, encompassing often a combination of preferred and common equity, have also been accompanied by conditions or restrictions, for instance requiring board seats for government representatives, and limiting or prohibiting dividend payments (Laeven and Valencia, 2008). These recapitalizations can often lead governments to own a majority share of a bank's capital, in which cases we classify the intervention as a nationalization, together with outright nationalization cases. Finally, we also report if the treasury or the central bank engaged in asset purchases to support the banking system and whether an asset management company was established to administer or resolve these assets.

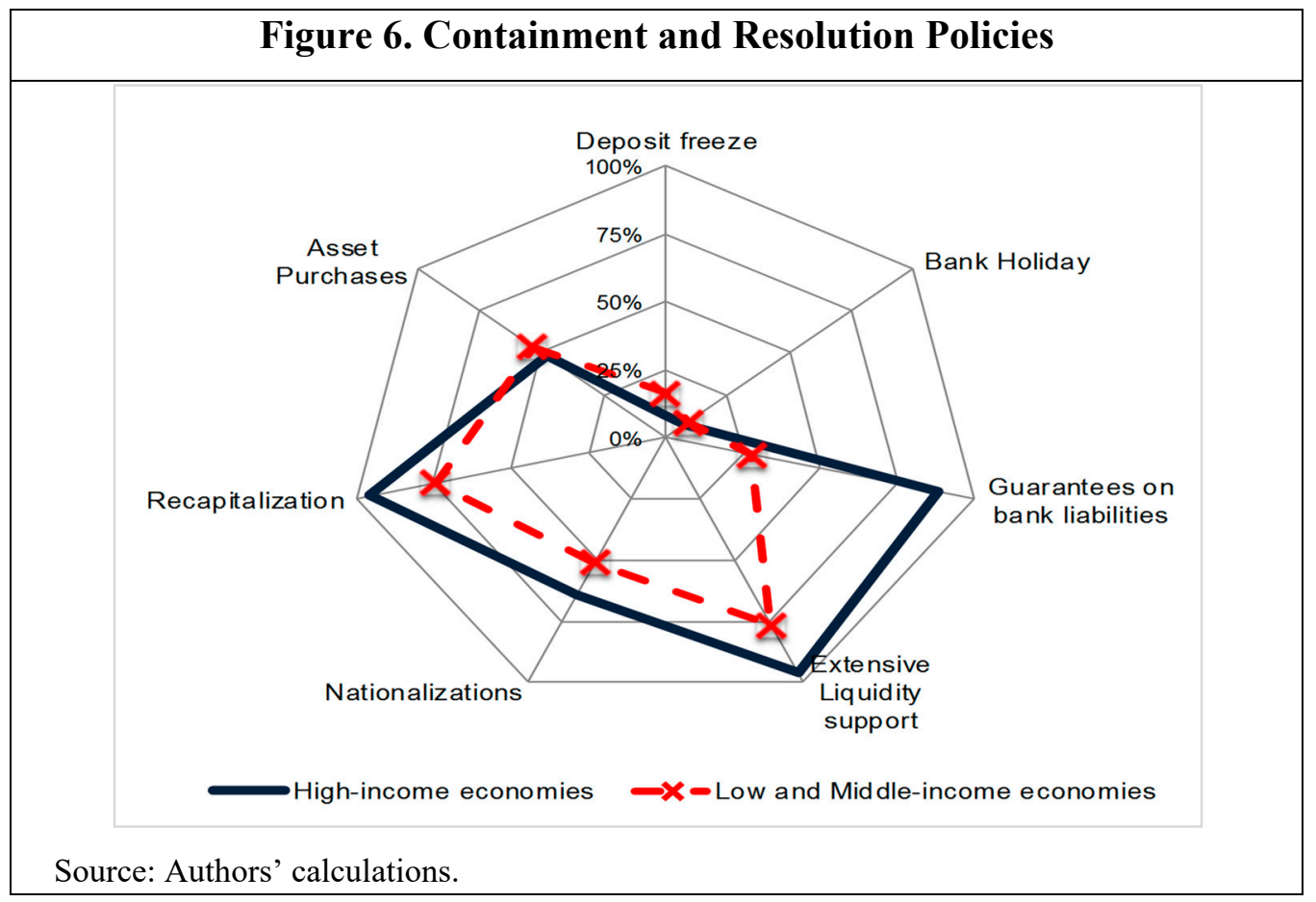

The differences in financial policy mix to resolve banking crises between high income and low-and middle-income economies is shown in Figure 6. The figure makes it clear that countries of both income groups resort broadly to the same types of policies to resolve systemic banking crises, except for guarantees. Significant guarantees on bank liabilities are more common among high-income countries, arguably because of generally better institutions or fiscal space that make the guarantees more credible. However, as noted in Claessens and others (2011), guarantees during the global financial crises were on average less comprehensive (i.e., more targeted) than in countries of lower income levels. In those countries, governments tended to announce blanket guarantees of banks' liabilities. In many cases, limited protection of deposits was introduced after a banking crisis (Laeven and 
Valencia, 2013). The absence of these schemes in many episodes in low and middle-income countries may have prompted policymakers to announce comprehensive guarantees of bank liabilities.

\section{B. Macro Policies}

In addition to using financial sector intervention measures to resolve banking crises, policymakers often use monetary and fiscal policy to mitigate their economic consequences. But as we report in this section, there is a difference between the use of these tools among high-income and low- and middle-income countries.

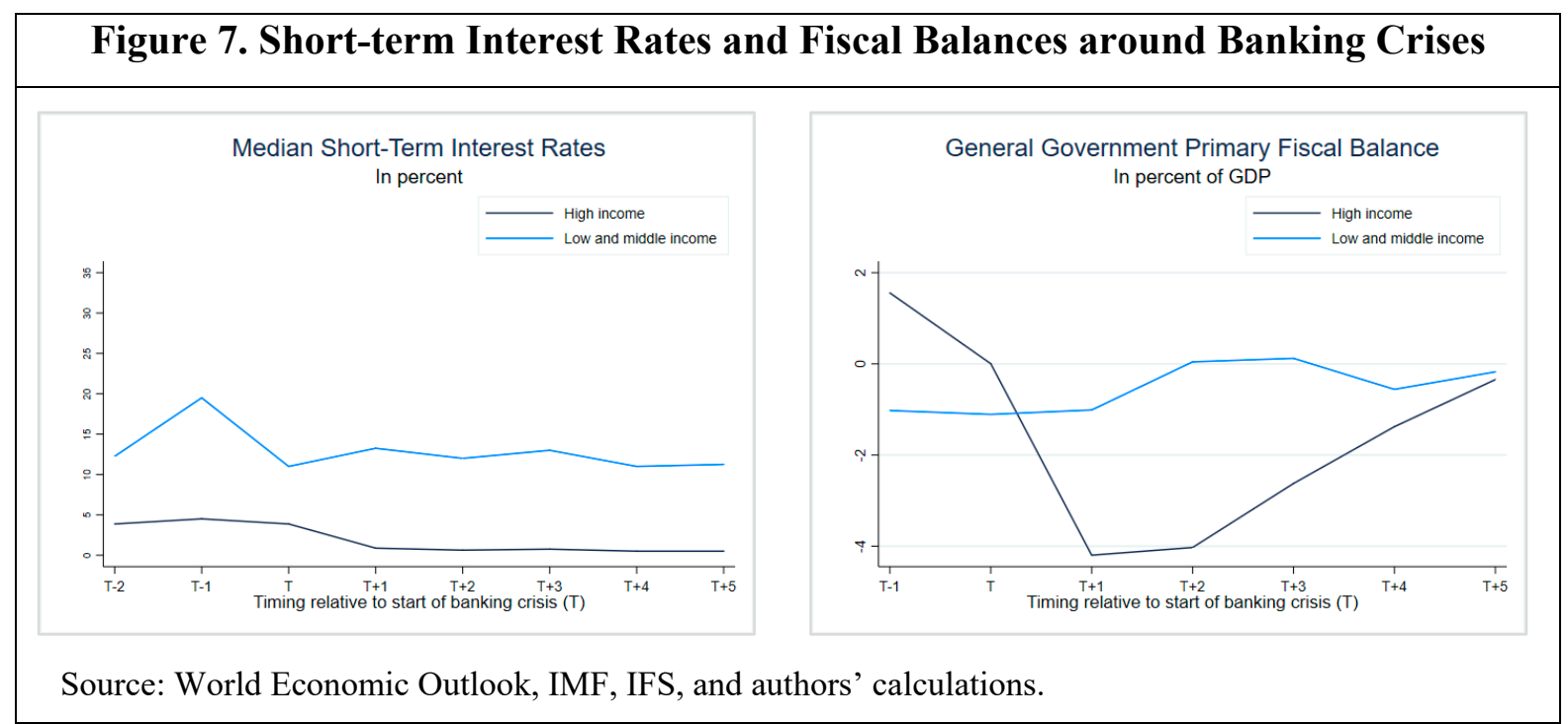

We trace the median evolution of short-term interest rates around systemic banking crises to gauge whether countries tended to ease or tighten monetary policy. Figure 7 shows that in high-income countries, short-term interest rates declined to a median level very close to zero in the year after the start of the crisis, from a median of about 5 percent. In contrast, the median short-term interest rate increases in low and middle-income countries, reflecting the often-limited space to conduct countercyclical monetary policy at times of heightened financial distress in these countries. ${ }^{14}$ Concerns about sharp currency depreciations and the resulting impact on private balance sheets exposed to exchange rate risk often force these countries to raise interest rates, ultimately leading also to sharper deterioration in banks' asset quality.

A similar outcome emerges when comparing the evolution of primary fiscal balances. While the median primary balance tends to deteriorate sharply in high-income countries, it

\footnotetext{
${ }^{14}$ Laeven and Valencia (2013) report also the increase in reserve money across episodes, which captures also the use of unconventional monetary policy, to also conclude the greater use of monetary policy in high-income countries.
} 
improves in low and middle-income countries. The latter group is forced to adopt a procyclical fiscal policy as these countries tend to face limited financing options in those circumstances.

\section{CRISIS OUTCOMES}

We collect and report data on the following outcomes for banking crises: i) the direct fiscal costs, measured as fiscal outlays linked to government intervention policies in the banking system; ii) a broader measure of fiscal costs, determined by the increase in public debt; iii) peak nonperforming loans (NPLs); iv) crisis duration, measured in number of years between the start and end of the crisis; and v) output losses.

\section{A. Fiscal Costs of Banking Crises}

We measure fiscal costs of banking crises as the sum of all fiscal outlays directly linked to government interventions to stabilize the banking system since the start of the crisis. These interventions include capital injections in financial institutions, operating costs of agencies or entities such as asset management companies, exercised public guarantees, and any other fiscal cost directly attributable to the rescue of financial institutions.

In reporting the fiscal costs of a banking crisis episode, we normalize the outlays by the nominal gross domestic product of the year in which they are incurred and sum them up. We also report these fiscal costs in percent of financial system assets, where the latter are measured as of the year before the start of the banking crisis. In reporting fiscal costs, we do not include government guarantees of bank liabilities or assets because they do not represent an outlay, ${ }^{15}$ although they are critical if one wanted to measure the total ex-ante risk taken by the public sector during the early stages of a banking crisis. Our ex-post analysis focuses on the actual fiscal costs of a banking crisis episode. ${ }^{16}$ Data on fiscal costs are collected from official country publications, supranational agencies, and IMF staff reports. ${ }^{17}$

\footnotetext{
${ }^{15}$ Our calculation of fiscal costs also excludes deferred tax assets (i.e. for Spain, these deferred tax assets amounted to $€ 70$ billion as of end-2016 according to IMF, 2017).

${ }^{16}$ The fiscal costs are reported in percent of GDP where nominal outlays have been converted in domestic currency and are divided by the nominal GDP of the corresponding year when the outlays took place.

${ }^{17}$ The fiscal costs and recoveries for this paper are taken from Laeven and Valencia (2013). For episodes starting in 2007 or later, fiscal costs and recoveries have been updated using national official publications. For European countries, whenever national sources did not publish information on these costs, we took data from the European commission scoreboard and Eurostat (http://ec.europa.eu/eurostat/web/government-financestatistics/excessive-deficit/supplemtary-tables-financial-crisis).
} 


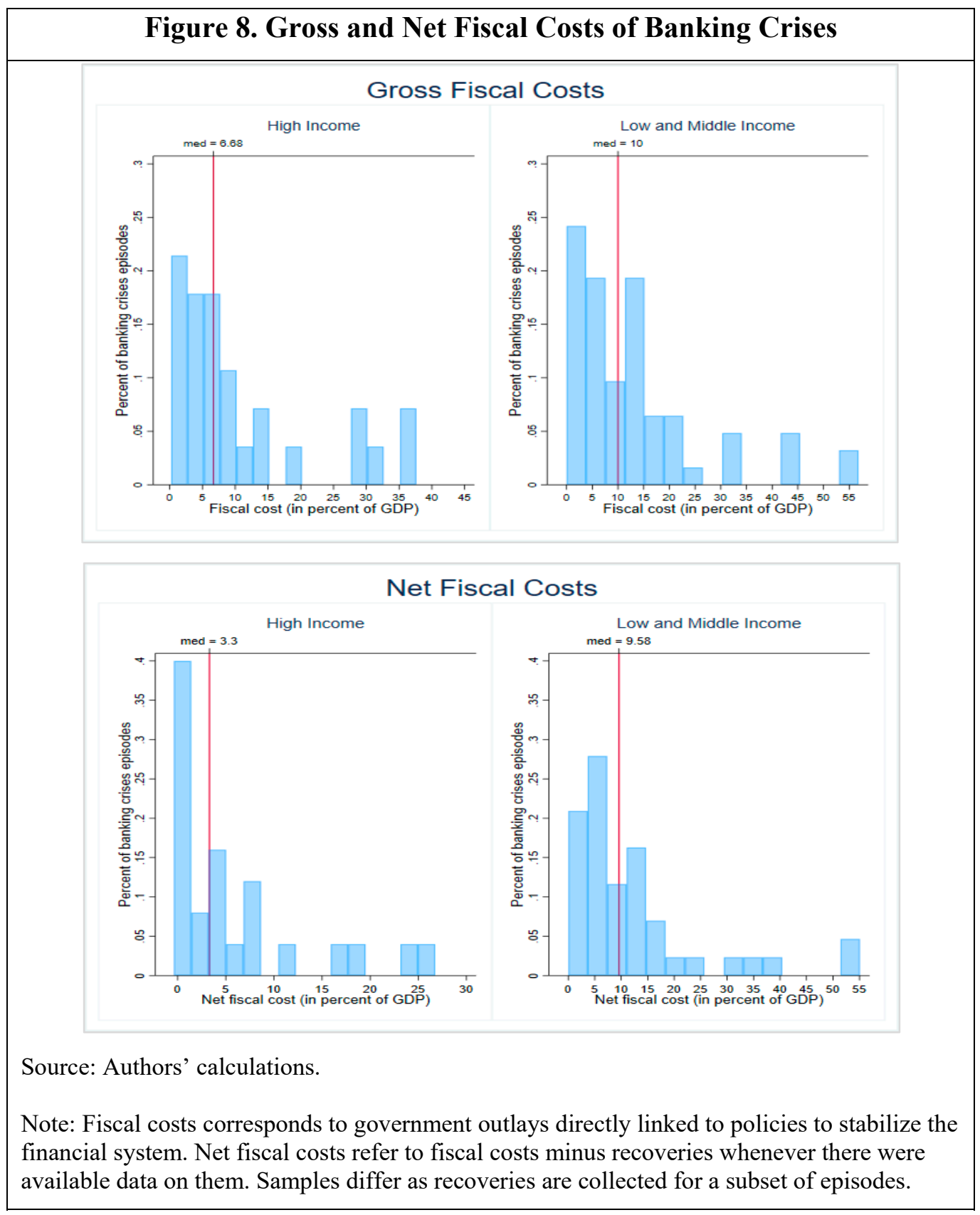

We collect recoveries of government outlays for a subset of episodes using the same data sources from which we collect fiscal costs. Data on recoveries allow us to report the net fiscal cost (i.e., outlays minus recoveries) of a banking crisis episode. We define recoveries as proceeds from sales of financial assets - acquired to resolve a banking crisis - revenues from fees on guarantees, dividends, interest, and any other cash inflow for the government that can be directly attributable to unwinding financial sector intervention measures. Our definition of recoveries means that we exclude unrealized capital gains on assets that are still 
on the government balance sheet, which implies that over a longer horizon, recoveries can exceed what we report in our database. ${ }^{18}$

The histograms in Figure 8 show substantial variation in the fiscal costs of systemic banking crises episodes, both in high-income and low and middle-income economies. Still, the median cost for crises in high-income countries is 6.7 percent of GDP and 10 percent of GDP for low and middle-income countries. The difference in fiscal costs between the two groups of countries increases to slightly above 6 percentage points of GDP after subtracting recoveries: The median net fiscal cost reaches 3.3 percent of GDP for high-income countries and 9.6 percent of GDP for low- and middle-income countries.

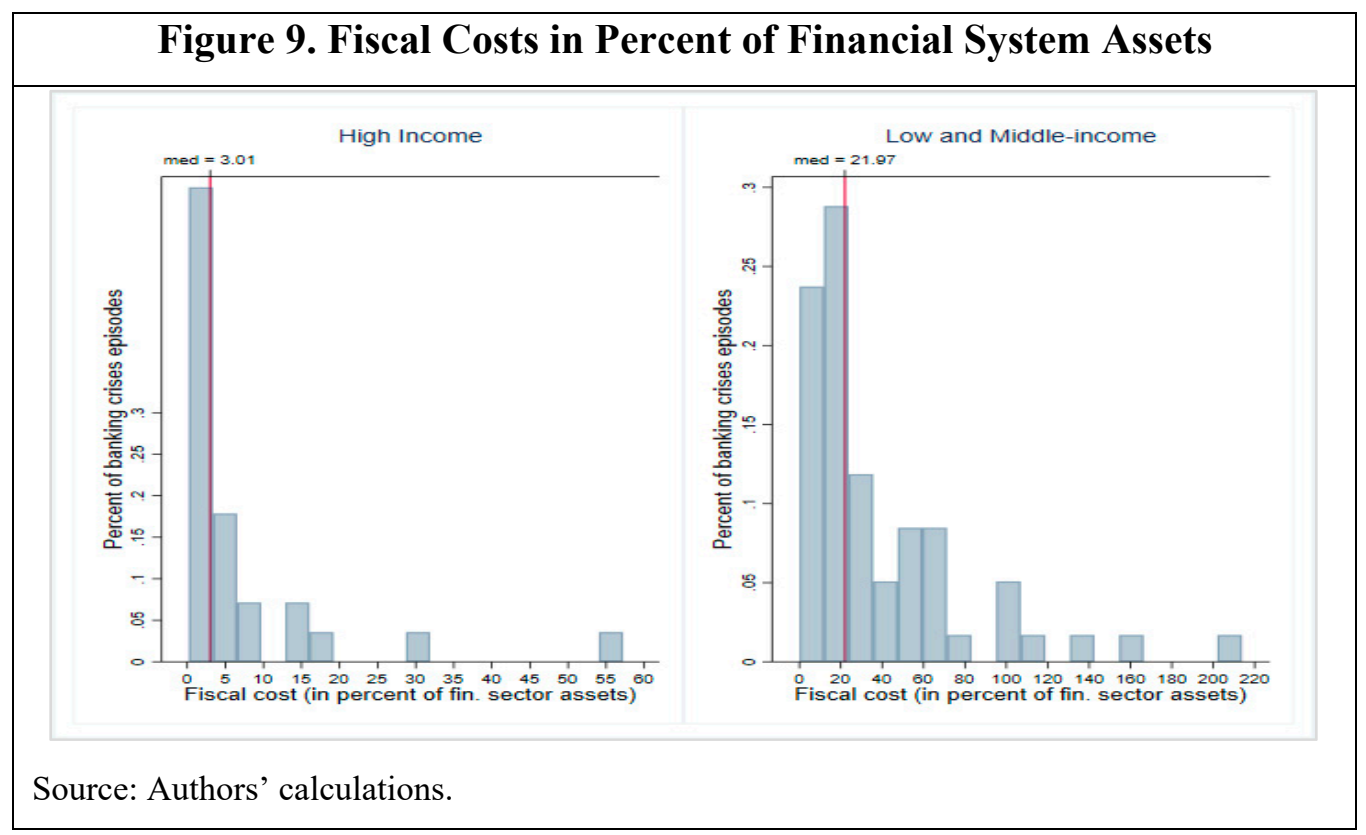

The difference in fiscal costs between the two groups of countries becomes even more pronounced when fiscal costs are measured relative to the size of the financial system, as shown in Figure 9. ${ }^{19}$ Relative to the size of financial systems, banking crises appear to have

\footnotetext{
${ }^{18}$ A case in point is Iceland, where we report net fiscal costs for 3.3 percent of GDP, which excludes bank equity held by the government valued at approximately 12 percent of GDP in 2016. This exclusion explains the bulk of the difference between our estimates of the net fiscal costs and the -9 percent of GDP reported in the 2016 IMF Article IV Staff Report.

${ }^{19}$ For most countries, the financial system assets data are taken from the World Bank's Financial Structure database and consist of domestic claims on the private sector by banks and non-bank financial institutions. In the case of European Union countries, for which cross-border claims can be sizeable, we instead use data from the European Central Bank (ECB) on the consolidated assets of financial institutions (excluding the Eurosystem and other national central banks), after netting out the aggregated balance sheet positions between financial institutions. Moreover, in the case of Iceland where cross-border claims are also sizable we use the assets of monetary and other financial institutions obtained from its national central bank.
} 
been much costlier, in terms of direct fiscal costs, in low- to middle-income economies. But these differences may also be the outcome of the greater reliance on macroeconomic policy tools, as noted in the previous section, which reduces the burden on financial sector policies to resolve the crisis. ${ }^{20}$

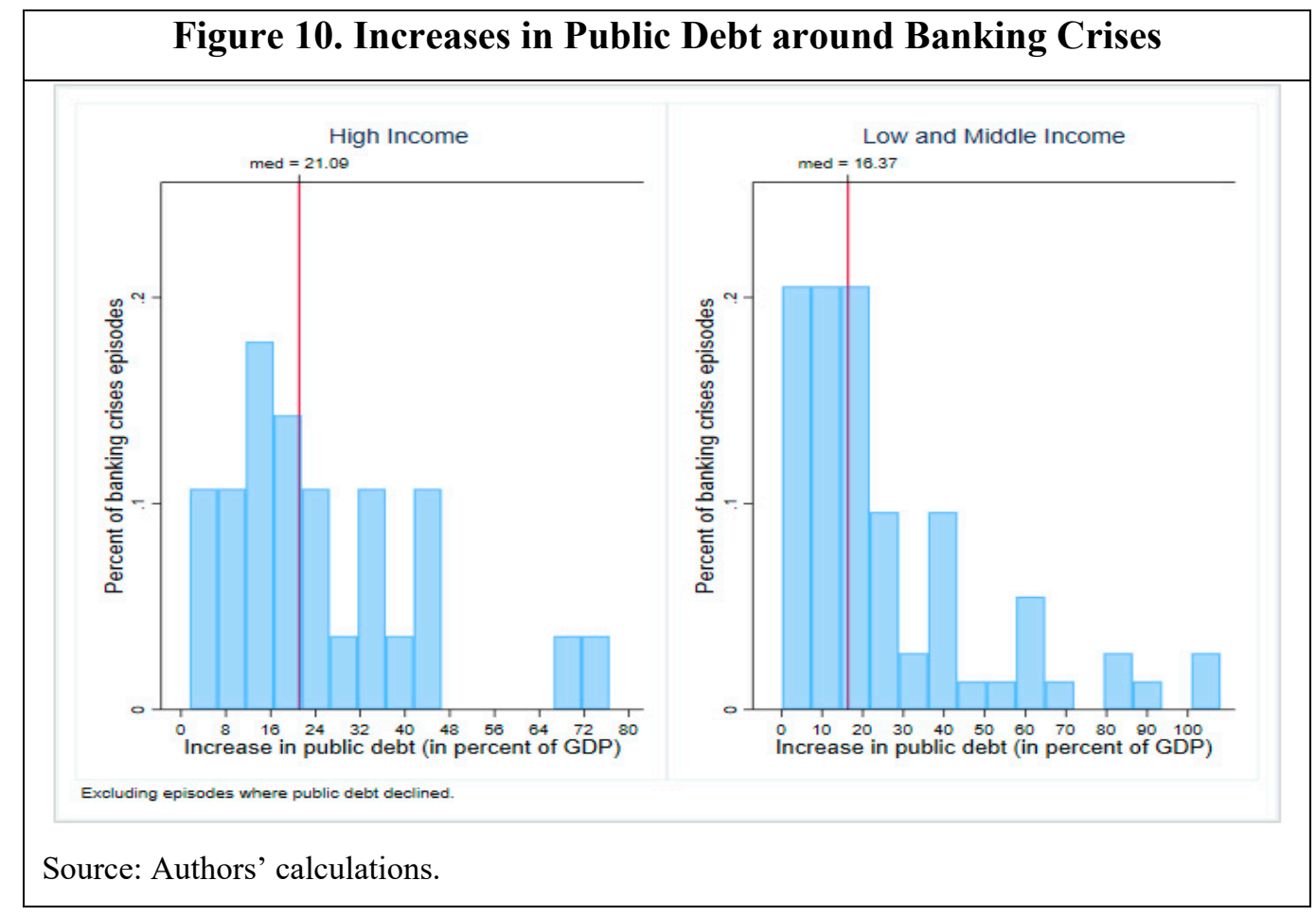

The use of fiscal space leads also to larger increases in public debt—our broader measure of fiscal costs of banking crises - in high-income countries compared to low and middle-income countries. Discretionary fiscal policy and automatic stabilizers affect directly this broader measure of fiscal costs of crises. These factors play a much smaller role in driving up public debt after a banking crisis in low- and middle-income countries. The median increase in public debt, measured over $\mathrm{T}-1, \mathrm{~T}+3$, where $\mathrm{T}$ is the starting year of the banking crisis, reaches 21.1 percent of GDP in high-income countries compared to 16.4 percent of GDP in low- and middle-income countries (Figure 10). ${ }^{21}$

\footnotetext{
${ }^{20} \mathrm{~A}$ handful of episodes appear with fiscal costs of more than 100 percent of financial system assets. This anomaly is the outcome of hyperinflation, since we take financial system assets as of the year preceding the banking crisis and fiscal outlays as of the year when they are incurred.

${ }^{21} \mathrm{We}$ approximate the increase in public debt by computing the difference between pre- and post-crisis debt projections. For crises starting in 2007 or later, we use as pre-crisis projected debt increase, between T-1 and $\mathrm{T}+3$, reported in the World Economic Outlook (WEO) issued in the fall of the year before the crisis start date (T) while the post-crisis actual debt increase, again over T-1 and T+3, from the Fall 2017 WEO. The ratios to GDP are computing using the latest GDP series. For past episodes, we simply report the actual change in debt.
} 


\section{B. Peak Nonperforming Loans}

The sharper deterioration in asset quality of banks in low- and middle-income countries can be noted by looking at the peak nonperforming loans (NPLs) across crisis episodes. Figure 11 shows the distribution of peak NPLs in the two groups of countries. In both income groups there is quite a bit of dispersion in the distribution, although in about 70 percent of crises in high-income countries, NPLs never surpassed 20 percent of total loans. The median peak NPL among crises in countries within this income bracket slightly exceeds 11 percent. In contrast, the median peak NPL reaches 30 percent among crises episodes in low and middle-income economies. While cross-country differences in the definition of NPLs makes it difficult to directly compare levels of NPLs across countries, the systematic and sizable difference between the two groups is unlikely to be entirely driven by differences in definitions.

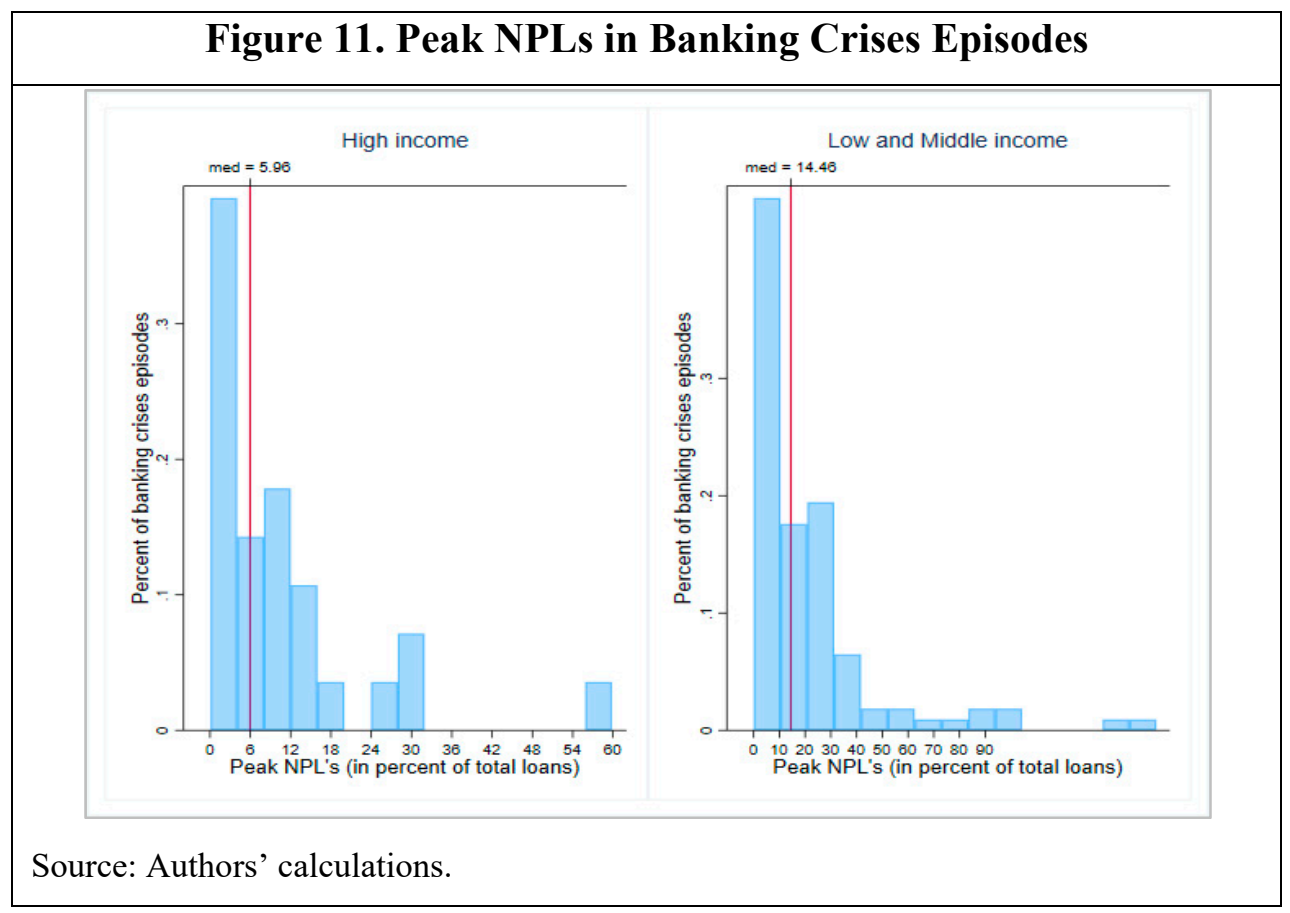

\section{Systemic Banking Crisis Duration}

Following the same definition as in Laeven and Valencia (2013), we also report end dates for each crisis episode, defined as the year before both real GDP growth and real credit growth are positive for at least two consecutive years. ${ }^{22}$ The rationale for identifying the end of a

\footnotetext{
${ }^{22}$ In computing end dates, we use bank credit to the private sector (in national currency) from IFS (line 22d). Bank credit series are deflated using CPI from WEO. GDP in constant prices (in national currency) also comes from the WEO. When credit data are not available, the end date is determined as the first year before GDP growth is positive for at least two years. When the definition is met in the first year of the crisis, then we set the crisis end year equal to the starting year.
} 
banking crisis through this approach hinges on the notion that a deterioration in bank solvency can disrupt the supply of credit (e.g. Bernanke and Gertler, 1987; Van Den Heuvel, 2006; Valencia, 2014; Abbasi and others, 2016) and these disruptions to the supply of credit can have real effects (e.g. Peek and Rosengren, 1997; Ashcraft, 2005; Kroszner and others, 2007; Dell'Ariccia and others, 2008; and Alfaro and others, 2017). Therefore, we look for evidence of a reversal in the negative effects of a banking crisis.

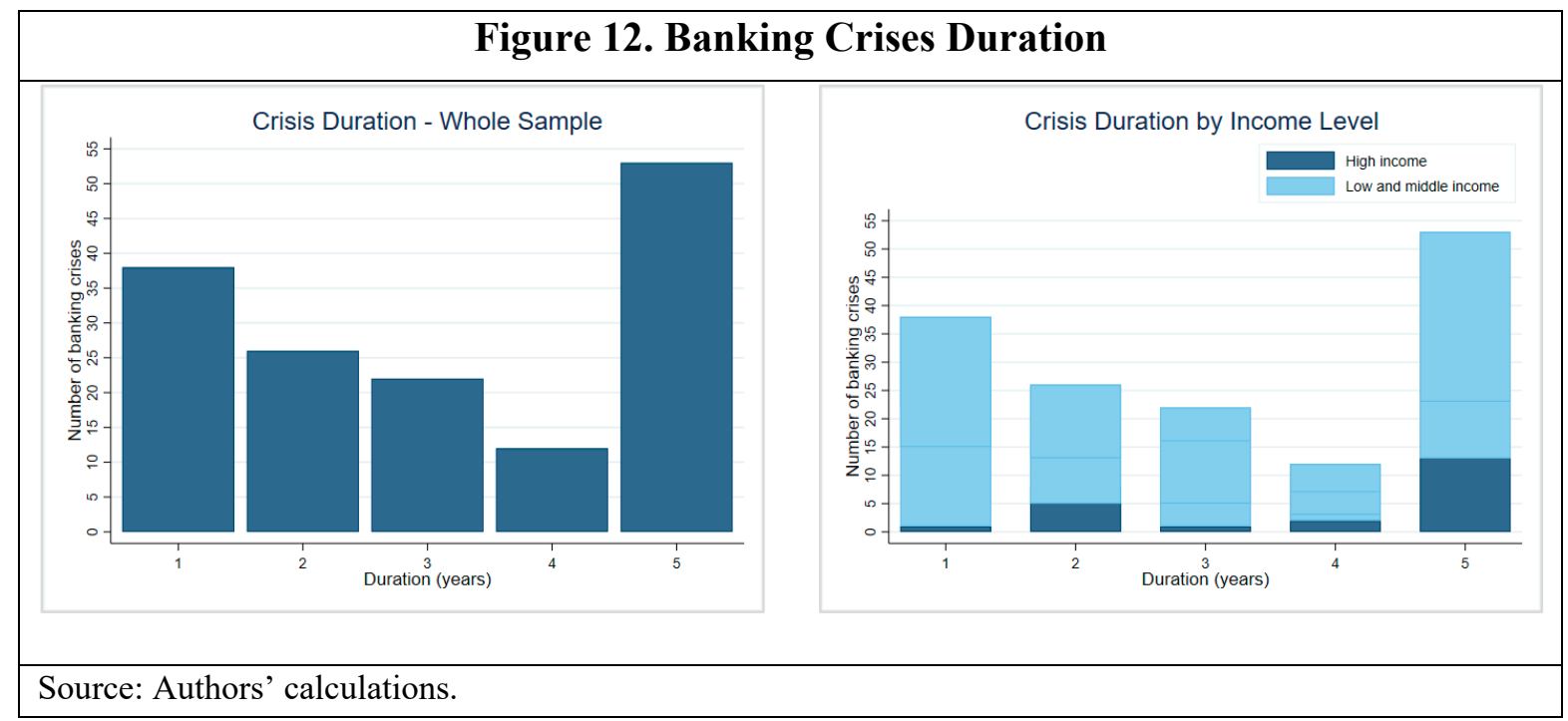

In all cases, we truncate the duration of a crisis at five years, starting from the first year of the crisis. The rationale for this truncation is twofold: first, our metric is based on credit stocks not flows (new lending), and stocks are affected by write-offs and restructurings. Therefore, a potential measurement error in the recovery of new lending could bias upwards the duration of the crisis episode. Second, as the length of time increases, our simple metric may start picking up the impact of other shocks. Therefore, whenever we report a crisis lasting five years, it should be read as five years or more. Figure 12 shows the distribution of the estimated duration of banking crisis episodes. The chart on the left shows that, according to our definition of end dates, about two-thirds of crises ended in less than five years. But these aggregate statistics mask some important differences among countries of different income levels. More than half of the episodes we record in high-income countries experienced crises that were quite persistent, lasting five years or more. In contrast, most crises in low and middle-income countries lasted four years or less.

Crisis severity may be an important factor explaining these differences in duration as many crises in high-income countries corresponded to the global financial crisis. At the same time, larger financial systems and institutions in these countries adds a layer of complexity to the resolution of the crisis, which could help explain the longer duration of crises. Finally, the ability of high-income countries to rely also on monetary and fiscal policy to mitigate the real effects of banking crises may also discourage more active bank restructuring which could ultimately prolong the duration of a crisis (Claessens et al., 2011). 


\section{Output Losses}

We report output losses associated with banking crises episodes, computed as deviations of actual GDP from its trend. ${ }^{23}$ The output losses are reported in cumulative terms over [T, $\mathrm{T}+3$ ], with $\mathrm{T}$ denoting the starting year of the crisis, and expressed in percent of one year's trend GDP. It is important to note that these losses should not be interpreted as solely stemming from banking crises, as they may include the impact of other shocks happening around crises. They should instead be read as what happens to output in the aftermath of a banking crisis. While admittedly the level of output losses is sensitive to how the trend is calculated, Laeven and Valencia (2013) showed that the ranking of crises is robust to using alternative sample periods when computing the trend. Therefore, the metric is primarily adequate to capture the relative size and heterogeneity of output losses across crises.

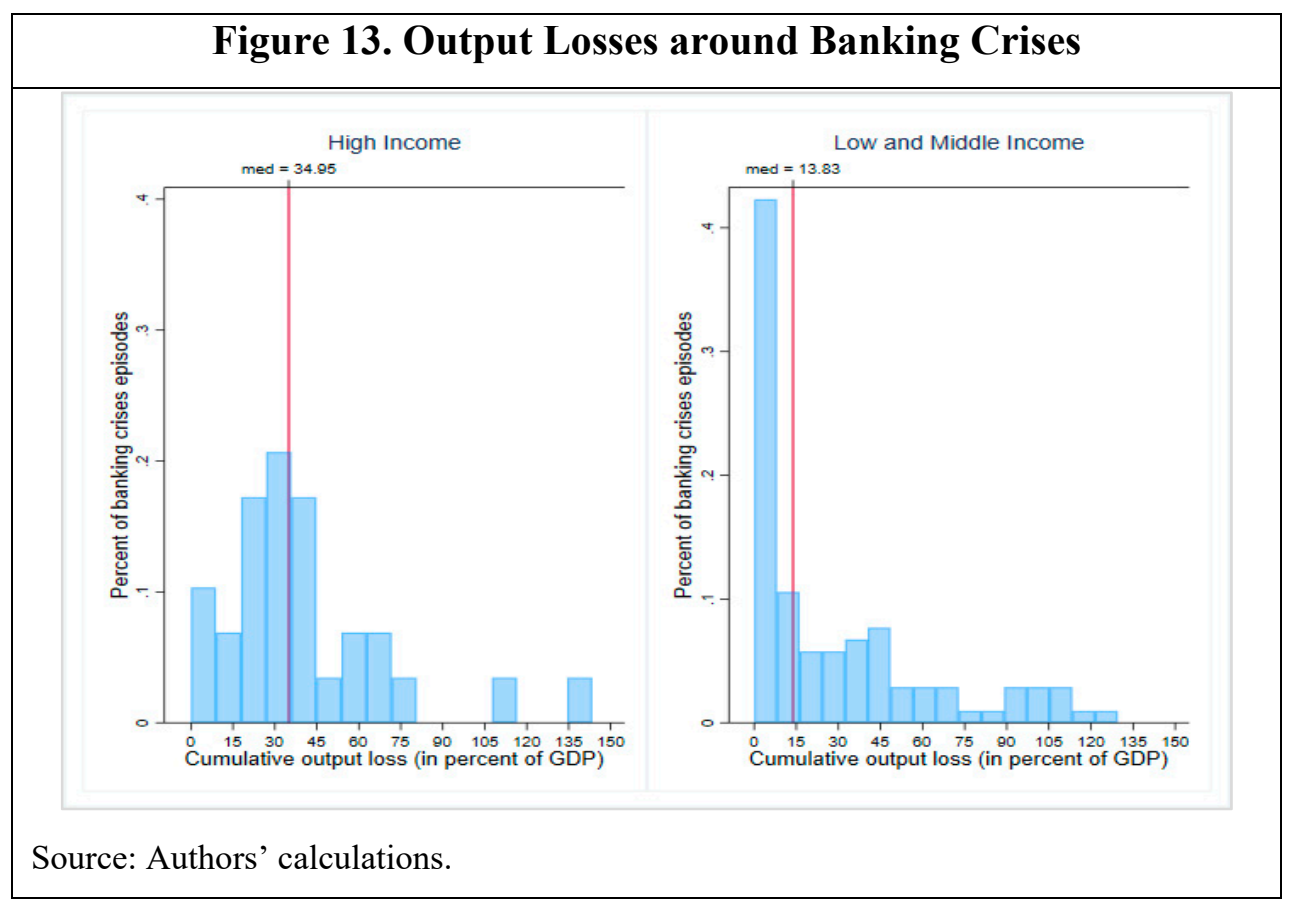

Figure 13 shows that the output losses in high-income countries tend to be much larger than those in low and middle-income countries. As with the earlier result on crisis duration, the larger output losses in high-income countries could be explained by the presence of larger and deeper financial systems, whose disruption has stronger effects on the real economy.

\footnotetext{
${ }^{23}$ Output losses are computed as the cumulative sum of the differences between actual and trend real GDP over the period [T, $T+3]$, expressed as a percentage of trend real GDP, with $T$ the starting year of the crisis. Trend real GDP is computed by applying an HP filter (with $\lambda=100$ ) to the log of real GDP series over [T-20, T-1] or the longest available series as long it includes at least 4 pre-crisis observations. Real GDP is extrapolated using the trend growth rate over the same period. Real GDP data come from the fall 2017 WEO.
} 
The evolution of output in the aftermath of banking crises suggest that these episodes tend to be followed by a very persistent decline in the level of real output, as highlighted in Figure 14. This stylized fact is consistent with new and old empirical work assessing the real consequences of banking crises which has highlighted the persistent real effects of these episodes (see for instance Cerra and Saxena, 2008, 2017; Abiad and others, 2014; Jorda and others, 2015; and Romer and Romer, 2017, 2018). ${ }^{24}$ However, this persistence in the decline of output in the aftermath of banking crises appears to be much more pronounced, on average, in high-income countries than in low- and middle-income countries, as suggested by Figure 14. ${ }^{25}$ Aslam and others (forthcoming) look at the recovery in the aftermath of banking crises and find that output remains below trend for longer in advanced economies than in emerging economies, consistent with the simple stylized fact presented here.

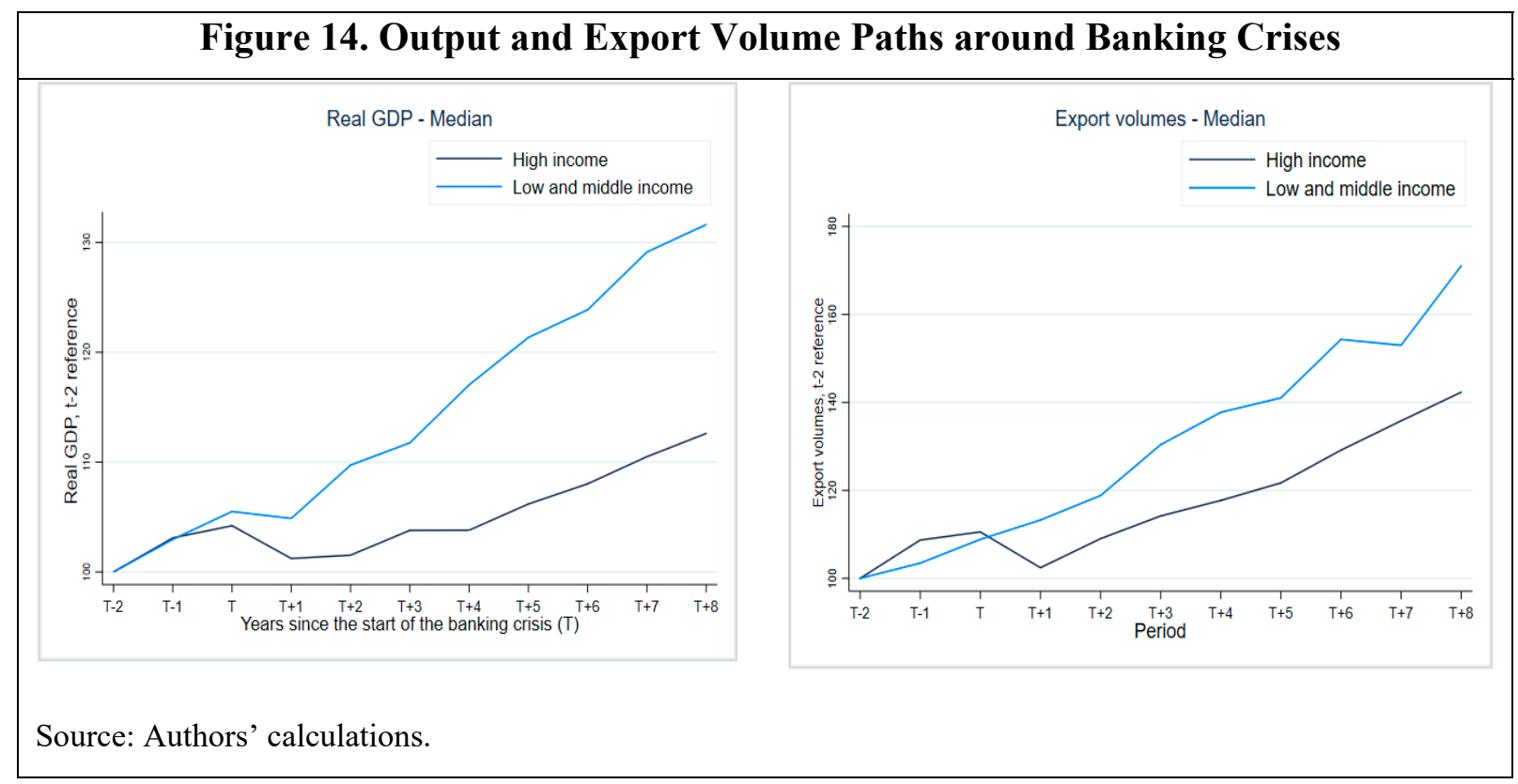

In addition to differences in the size of financial systems between high- and low and middleincome countries, one additional element that could explain the difference in output paths in the aftermath of crises is the evolution of export volumes. Consistent with the slowdown in trade volumes documented in IMF (2016), Figure 14 shows a sluggish evolution in export volumes in the aftermath of banking crises in high-income countries, comprising mostly episodes during the global financial crisis. In contrast, the median path among crisis episodes in low-and middle-income countries does not show a slowdown. Countries in this income

\footnotetext{
${ }^{24}$ Cerra and Saxena (2017) argue that, on average, all types of recessions, not just those associated with financial and political crises, lead to permanent output losses.

25 This conclusion is different than the one in Mishkin (1996), written prior to the global financial crisis which affected mostly advanced countries with an intensity and global proportion not seen since the Great Depression.
} 
group, comprising episodes mostly prior to the global financial crisis, often benefited from a boost from external demand that resulted in a faster recovery in the aftermath of the banking crisis.

\section{Conclusions}

A decade since the start of the global financial crisis has allowed sufficient time for some crisis episodes to end. However, many countries have been left with important legacy issues in terms of permanent output losses, elevated levels of public debt, policy support still to be fully unwound, and significant government ownership of financial assets. While these crisis episodes have enriched our experience, much remains to be learned regarding how to predict banking crises, how to prevent them, and how best to resolve them. To make progress in such an ambitious endeavor, a key prerequisite is the availability of high-quality data on banking crises. To help in this direction, this paper provides a comprehensive database on systemic banking crises during the period 1970-2017, reflecting updates to outcomes from banking crises reported in our earlier releases (Laeven and Valencia, 2008, 2010, and 2013) and new events that occurred since then.

It is our hope that these data will assist academics and policymakers in improving our understanding of the causes and consequences of banking crises, and how best to resolve them. While only a few countries have experienced a crisis in recent years, this period may just be the lull before the storm. 


\section{References}

Abbassi, Puriya, Raj Iyer, and Francesc R. Tous, 2016, "Securities Trading by Banks and Credit Supply: Micro-Evidence,” Journal of Financial Economics, Vol. 121(3), 569594.

Abiad, Abdul, Ravi Balakrishnan, Petya Koeva Brooks, Daniel Leigh, and Irina Tytell, 2014, "What's the Damage? Medium-Term Output Dynamics after Financial Crises, In: Claessens, Stijn, M. Ayhan Kose, Luc Laeven, and Fabian Valencia (eds.). Financial Crises: Causes, Consequences, and Policy Responses, International Monetary Fund, Washington D.C.

Alfaro, Laura, Manuel Garcia-Santana, and Enrique Moral-Benito, 2017, "Credit Supply Shocks, Network Effects, and the Real Economy," Harvard Business School manuscript.

Aslam, Aqib, Patrick Blagrave, Eugenio Cerutti, Sung Eun Jung, and Carolina OsorioBuitron, forthcoming, "Recessions and Recoveries: Are EMs different from AEs?" IMF Working Paper.

Ashcraft, Adam, 2005, "Are Banks Really Special? New Evidence from the FDIC-Induced Failure of Healthy Banks,” American Economic Review, Vol. 95, pp. 1712-1730.

Baron, Matthew, Emil Verner, and Wei Xiong, 2018, "Identifying Banking Crises," Princeton University manuscript.

Beim, David and Charles Calomiris, 2001, "Emerging Financial Markets.” Appendix to Chapter 1. New York: McGraw-Hill/Irwin Publishers.

Bernanke, Ben and Mark Gertler, 1987, "Banking and Macroeconomic Equilibrium," In: New Approaches to Monetary Economics, ed. W. Barnett and K. Singleton, New York: Cambridge University Press.

Caprio, Gerard, and Daniela Klingebiel, 1996, "Bank Insolvencies: Cross-Country Experience,” Policy Research Working Paper No. 1620 (Washington: World Bank).

Cerra, Valerie and Sweta Saxena, 2008, "Growth Dynamics: The Myth of Economic Recovery," American Economic Review, Vol. 98(1), pp. 439-57.

Cerra, Valerie and Sweta Saxena, 2017, "Booms, Crises, and Recoveries: A New Paradigm of the Business Cycle and its Policy Implications," IMF Working Paper 2017/250.

Chaudron, Raymond and Jakob de Haan, 2014, "Dating banking crises using incidence and size of bank failures: Four crises reconsidered," Journal of Financial Stability, Vol. 15 , pp. $63-75$. 
Claessens, Stijn, Ceyla Pazarbasioglu, Luc Laeven, Marc Dobler, Fabian Valencia, Oana Nedelescu, Katharine Seal, 2011, "Crisis Management and Resolution: Early Lessons from the Financial Crisis," IMF Staff Discussion Note No. 11/05.

Claessens, Stijn, M. Ayhan Kose, Luc Laeven, and Fabian Valencia (eds.), 2014, Financial Crises: Causes, Consequences, and Policy Responses, International Monetary Fund, Washington D.C.

Dell'Ariccia, Giovanni, Enrica Detragiache, and Raghuram Rajan, 2008, "The Real Effects of Banking Crises,” Journal of Financial Intermediation, Vol. 17, pp. 89-112.

Dell'Ariccia, Giovanni, Maria Soledad Martinez Peria, Deniz O Igan, Elsie Addo Awadzi, Marc Dobler, and Damiano Sandri, 2018, "Trade-offs in Bank Resolution, IMF Staff Discussion note 18/02.

Demirgüç-Kunt, Asli and Enrica Detragiache, 1998, "The Determinants of Banking Crises: Evidence from Developed and Developing Countries”, IMF Staff Papers, Vol. 45 (1).

Fratzscher, Marcel, Arnaud Mehl, and Isabel Vansteenkiste, 2011, "130 Years of Fiscal Vulnerabilities and Currency Crashes in Advanced Economies," IMF Economic Review, Vol. 59, pp. 683-716.

Frankel, Jeffrey and Andrew Rose, 1996, "Currency Crashes in Emerging Markets: An Empirical Treatment," Journal of International Economics, Vol. 41, pp. 351-366.

Giannetti, Mariassunta and Andrei Simonov, 2013, "On the Real Effects of Bank Bailouts: Micro Evidence from Japan,” American Economic Journal: Macroeconomics, Vol. 5, pp.135-167.

Gourinchas, Pierre-Olivier and Maurice Obstfeld, 2012, "Stories of the Twentieth Century for the Twenty-First," American Economic Journal: Macroeconomics, Vol. 4(1), pp $226-65$.

Homar, Timotej, and Sweder J.G. van Wijnbergen, 2017, “Bank Recapitalization and Economic Recovery after Financial Crises," Journal of Financial Intermediation, Vol. 32, pp. 16-28.

Honohan, Patrick, and Luc Laeven, eds., 2005, Systemic Financial Crises: Containment and Resolution (Cambridge, UK: Cambridge University Press.

IMF, 2014, "From Banking to Sovereign Stress: Implications for Public Debt," IMF Board paper.

IMF, 2016, “Global Trade: What's behind the Slowdown?” IMF World Economic Outlook, Chapter 2, October. 
IMF, 2017, "Spain—Publication of Financial Sector Assessment Program DocumentationTechnical Note on Impaired Assets and Nonperforming Loans," IMF country report No. $17 / 343$.

Jorda, Oscar, Moritz Schularick, and Alan M. Taylor, 2015, "Leveraged Bubbles," Journal of Monetary Economics, Vol. 76, pp. S1-S20.

Kaminsky, Graciela and Carmen Reinhart, 1999, “The Twin Crises: The Causes of Banking and Balance-of-Payments Problems," American Economic Review, Vol. 89, pp. 473500 .

Kohlscheen, Emanuel, Fernando Avalos, and Andreas Schrimpf, 2017, "When the Walk Is Not Random: Commodity Prices and Exchange Rates, " International Journal of Central Banking, Vol. 13(2), pp. 121-158.

Kroszner, Randall, Luc Laeven, and Daniela Klingebiel, 2007, "Banking Crises, Financial Dependence, and Growth," Journal of Financial Economics, Vol. 84, pp. 187-228.

Laeven, Luc and Fabian Valencia, 2008, "Systemic Banking Crises: A New Database," IMF Working Paper No. 08/224, (Washington: International Monetary Fund).

Laeven, Luc and Fabian Valencia, 2010, "Resolution of Banking Crises: The Good, the Bad, and the Ugly," IMF Working Paper No. 10/44, (Washington: International Monetary Fund).

Laeven, Luc and Fabian Valencia, 2012, "The Use of Blanket Guarantees in Banking Crises", Journal of International Money and Finance, Vol. 1(5), pp. 1220-248.

Laeven, Luc, and Fabian Valencia, 2013a, "Systemic Banking Crises Database," IMF Economic Review, Vol. 61 (2), pp. 225-270.

Laeven, Luc and Fabian Valencia, 2013b, "The Real Effects of Financial Sector Interventions during Crises," Journal of Money, Credit, and Banking, Vol. 45(1), pp. $147-177$.

Mishkin, Frederic, 1996, "Understanding Financial Crises: A Developing Country Perspective”, NBER Working Paper No. 5600.

Peek, Joe, and Erik Rosengren, 1997, "The International Transmission of Financial Shocks: The Case of Japan," American Economic Review, Vol. 87(4), pp. 495-505.

Philippon, Thomas and Philipp Schnabl, 2013, "Efficient Recapitalization," Journal of Finance.

Reinhart, Carmen and Kenneth Rogoff, 2009, This Time is Different: Eight Centuries of Financial Folly, Princeton University Press. 
Reinhart, Carmen and Kenneth Rogoff, 2011, "From Financial Crash to Debt Crisis," American Economic Review, Vol. 101, pp. 1676-1706.

Romer, David and Christina Romer, 2017, "New Evidence on the Aftermath of Financial Crises in Advanced Countries," American Economic Review, Vol. 107(10), pp. 30723118.

Romer, David and Christina Romer, 2018, "Phillips Lecture - Why Some Times are Different: Macroeconomic Policy and the Aftermath of Financial Crises," Economica, Vol. 85, pp. 1-40.

Sandri, Damiano and Fabian Valencia, 2013, "Financial Crises and Recapitalizations," Journal of Money, Credit, and Banking, Vol 45(S2), pp. 59-86.

Schularick, Moritz, and Alan M. Taylor, 2012, "Credit Booms Gone Bust: Monetary Policy, Leverage Cycles, and Financial Crises, 1870-2008," American Economic Review, Vol. 102(2), pp. 1029-1061.

Stone, M., K. Fujita, and K. Ishi, 2011, "Should Unconventional Balance Sheet Policies Be Added to the Central Bank Toolkit?" IMF Working Paper 2011/145.

Sturzenegger, Federico and Jeromin Zettelmeyer, 2006, Debt Defaults and Lessons from a Decade of Crises. Cambridge: MIT Press.

Valencia, Fabian, 2014, "Banks' Precautionary Capital and Credit Crunches," Macroeconomic Dynamics, Vol. 18(8), pp. 1726-1750.

Van Den Heuvel, Skander, 2006, "The Bank Capital Channel of Monetary Policy," University of Pennsylvania unpublished manuscript.

World Bank, 2002, Global Development Finance. Appendix on Commercial Debt Restructuring. Washington, D.C.: World Bank. 


\section{Appendix}

Table 1. Crisis Dates

\begin{tabular}{|c|c|c|c|c|}
\hline Country & Banking & Currency & Sovereign & $\begin{array}{c}\text { Sovereign } \\
\text { (Restructuring) }\end{array}$ \\
\hline Albania & 1994 & 1997 & 1990 & 1992 \\
\hline Algeria & 1990 & 1988, 1994 & & \\
\hline Angola & $1980,1989,1995$ & 1991, 1996, 2015 & $\begin{array}{r}1988 \\
1982,2001,\end{array}$ & $\begin{array}{r}1992 \\
1993,2005,\end{array}$ \\
\hline Argentina & 2001 & $1975,1981,1987,2002,2013$ & 2014 & 2016 \\
\hline Armenia & 1994 & & & \\
\hline \multicolumn{5}{|l|}{ Australia } \\
\hline Austria & 2008 & & & \\
\hline Azerbaijan & 1995 & 2015 & & \\
\hline Bangladesh & 1987 & 1976 & & \\
\hline \multicolumn{5}{|l|}{ Barbados } \\
\hline Belarus & 1995 & 1997, 2009, 2015 & & \\
\hline Belgium & 2008 & & & \\
\hline Belize & & & $2007,2012,2017$ & $2007,2013,2017$ \\
\hline Benin & 1988 & 1994 & & \\
\hline \multicolumn{5}{|l|}{ Bhutan } \\
\hline Bolivia & 1986, 1994 & 1973,1981 & 1980 & 1992 \\
\hline $\begin{array}{l}\text { Bosnia and } \\
\text { Herzegovina }\end{array}$ & 1992 & & & \\
\hline Botswana & & 1984 & & \\
\hline Brazil & 1990,1994 & 1976, 1982, 1987, 1992, 1999, 2015 & 1983 & 1994 \\
\hline \multicolumn{5}{|l|}{ Brunei } \\
\hline Bulgaria & 1996 & 1996 & 1990 & 1994 \\
\hline Burkina Faso & 1990 & 1994 & & \\
\hline Burundi & 1994 & & & \\
\hline Cambodia & & 1971, 1992 & & \\
\hline Cameroon & 1987,1995 & 1994 & 1989 & 1992 \\
\hline \multicolumn{5}{|l|}{ Canada } \\
\hline $\begin{array}{l}\text { Cape Verde } \\
\text { Central African }\end{array}$ & 1993 & & & \\
\hline Rep. & 1976,1995 & 1994 & & \\
\hline Chad & 1983,1992 & 1994 & & \\
\hline Chile & 1976,1981 & 1972,1982 & 1983 & 1990 \\
\hline China, P.R. & 1998 & & & \\
\hline Colombia & 1982,1998 & 1985 & & \\
\hline Comoros & & 1994 & & \\
\hline $\begin{array}{l}\text { Congo, Dem. Rep. } \\
\text { of }\end{array}$ & 1983, 1991, 1994 & 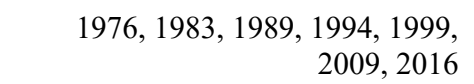 & 1976 & 1989 \\
\hline Congo, Rep. of & 1992 & 1994 & 1986 & 1992 \\
\hline Costa Rica & 1987,1994 & 1981, 1991 & $\begin{array}{r}1981 \\
1984,2001\end{array}$ & 1990 \\
\hline Côte d'Ivoire & 1988 & 1994 & 2010 & 1997,2010 \\
\hline Croatia & 1998 & & & \\
\hline Czech Republic & 1996 & & & \\
\hline Cyprus & 2011 & & 2013 & 2013 \\
\hline Denmark & 2008 & & & \\
\hline Djibouti & 1991 & & & \\
\hline
\end{tabular}




\begin{tabular}{|c|c|c|c|c|}
\hline Country & Banking & Currency & Sovereign & $\begin{array}{c}\text { Sovereign } \\
\text { (Restructuring) }\end{array}$ \\
\hline Dominica & & & 2002 & 2004 \\
\hline \multicolumn{5}{|l|}{ Dominican } \\
\hline Republic & 2003 & $1985,1990,2003$ & 1982,2003 & 1994,2005 \\
\hline & & & 1982, 1999, & 1995, 2000, \\
\hline Ecuador & 1982,1998 & 1982,1999 & 2008 & 2009 \\
\hline Egypt & 1980 & $1979,1990,2016$ & 1984 & 1992 \\
\hline El Salvador & 1989 & 1986 & & \\
\hline Equatorial Guinea & 1983 & 1980, 1994 & & \\
\hline Eritrea & 1993 & & & \\
\hline Estonia & 1992 & 1992 & & \\
\hline Ethiopia & & 1993 & & \\
\hline Fiji & & 1998 & & \\
\hline Finland & 1991 & 1993 & & \\
\hline France & 2008 & & & \\
\hline Gabon & & 1994 & 1986,2002 & 1994 \\
\hline Gambia, The & & 1985,2003 & 1986 & 1988 \\
\hline Georgia & 1991 & 1992, 1999 & & \\
\hline Germany & 2008 & & & \\
\hline Ghana & 1982 & 1978, 1983, 1993, 2000, 2009, 2014 & & \\
\hline Greece & 2008 & 1983 & 2012 & 2012 \\
\hline Grenada & & & 2004 & 2005,2015 \\
\hline Guatemala & & 1986 & & \\
\hline Guinea & 1985,1993 & 1982,2005 & 1985 & 1992 \\
\hline Guinea-Bissau & 1995,2014 & 1980,1994 & & \\
\hline Guyana & 1993 & 1987 & 1982 & 1992 \\
\hline Haiti & 1994 & 1992,2003 & & \\
\hline Honduras & & 1990 & 1981 & 1992 \\
\hline \multirow{2}{*}{\multicolumn{5}{|c|}{$\begin{array}{l}\text { China, P.R.: Hong } \\
\text { Kong }\end{array}$}} \\
\hline & & & & \\
\hline Hungary & 1991,2008 & & & \\
\hline Iceland & 2008 & $1975,1981,1989,2008$ & & \\
\hline India & 1993 & & & \\
\hline Indonesia & 1997 & 1979,1998 & 1999 & 2002 \\
\hline Iran, I.R. of & & $1985,1993,2000,2013$ & 1992 & 1994 \\
\hline Ireland & 2008 & & & \\
\hline Israel & 1983 & $1975,1980,1985$ & & \\
\hline Italy & 2008 & 1981 & & \\
\hline Jamaica & 1996 & $1978,1983,1991$ & 1978,2010 & $\begin{array}{r}1990,2010, \\
2013\end{array}$ \\
\hline Japan & 1997 & & & \\
\hline Jordan & 1989 & 1989 & 1989 & 1993 \\
\hline Kazakhstan & 2008 & 1999,2015 & & \\
\hline Kenya & 1985,1992 & 1993 & & \\
\hline Korea & 1997 & 1998 & & \\
\hline Kuwait & 1982 & & & \\
\hline Kyrgyz Republic & 1995 & 1997 & & \\
\hline Lao People's Dem. & & & & \\
\hline Rep. & & 1972, 1978, 1986, 1997 & & \\
\hline Latvia & 1995,2008 & 1992 & & \\
\hline Lebanon & 1990 & 1984,1990 & & \\
\hline Lesotho & & 1985,2015 & & \\
\hline Liberia & 1991 & & 1980 & \\
\hline Libya & & 2002 & & \\
\hline
\end{tabular}




\begin{tabular}{|c|c|c|c|c|}
\hline Country & Banking & Currency & Sovereign & $\begin{array}{c}\text { Sovereign } \\
\text { (Restructuring) }\end{array}$ \\
\hline Lithuania & 1995 & 1992 & & \\
\hline Luxembourg & 2008 & & & \\
\hline Macedonia & 1993 & & & \\
\hline Madagascar & 1988 & 1984, 1994, 2004 & 1981 & 1992 \\
\hline Malawi & & 1994, 2012 & 1982 & 1988 \\
\hline Malaysia & 1997 & 1998 & & \\
\hline Maldives & & 1975 & & \\
\hline Mali & 1987 & 1994 & & \\
\hline Mauritania & 1984 & 1993 & & \\
\hline \multicolumn{5}{|l|}{ Mauritius } \\
\hline Mexico & 1981,1994 & 1977, 1982, 1995 & 1982 & 1990 \\
\hline Moldova & 2014 & 1999 & 2002 & 2002 \\
\hline Mongolia & 2008 & 1990, 1997 & & \\
\hline Morocco & 1980 & 1981 & 1983 & 1990 \\
\hline Mozambique & 1987 & 1987,2015 & 1984 & 1991 \\
\hline Myanmar & & 1975, 1990, 1996, 2001,2007, 2012 & & \\
\hline Namibia & & 1984,2015 & & \\
\hline Nepal & 1988 & 1984,1992 & & \\
\hline Netherlands & 2008 & & & \\
\hline New Caledonia & & 1981 & & \\
\hline New Zealand & & 1984 & & \\
\hline Nicaragua & 1990,2000 & $1979,1985,1990$ & 1980 & 1995 \\
\hline Niger & 1983 & 1994 & 1983 & 1991 \\
\hline Nigeria & 1991, 2009 & $1983,1989,1997,2016$ & 1983 & 1992 \\
\hline Norway & 1991 & & & \\
\hline Pakistan & & 1972 & & \\
\hline Panama & 1988 & & 1983 & 1996 \\
\hline Papua New Guinea & & 1995 & & \\
\hline Paraguay & 1995 & 1984, 1989, 2002 & 1982 & 1992 \\
\hline Peru & 1983 & $1976,1981,1988$ & 1978 & 1996 \\
\hline Philippines & 1983,1997 & 1983,1998 & 1983 & 1992 \\
\hline Poland & 1992 & & 1981 & 1994 \\
\hline Portugal & 2008 & 1983 & & \\
\hline Romania & 1998 & 1996 & 1982 & 1987 \\
\hline Russia & 1998,2008 & 1998,2014 & 1998 & 2000 \\
\hline Rwanda & & 1991 & & \\
\hline St. Kitts and Nevis & & & & 2012 \\
\hline \multicolumn{5}{|l|}{ São Tomé and } \\
\hline Principe & 1992 & 1987, 1992, 1997 & & \\
\hline Senegal & 1988 & 1994 & 1981 & 1996 \\
\hline Serbia, Republic of & & 2000 & & \\
\hline Seychelles & & 2008 & 2008 & 2009 \\
\hline Sierra Leone & 1990 & $1983,1989,1998$ & 1977 & 1995 \\
\hline \multicolumn{5}{|l|}{ Singapore } \\
\hline Slovak Republic & 1998 & & & \\
\hline Slovenia & 1992,2008 & & & \\
\hline South Africa & & 1984, 2015 & 1985 & 1993 \\
\hline South Sudan & & 2015 & & \\
\hline Spain & 1977,2008 & 1983 & & \\
\hline Sri Lanka & 1989 & 1978 & & \\
\hline Sudan & & $1981,1988,1993,2012$ & 1979 & 1985 \\
\hline Suriname & & $1990,1995,2001,2016$ & & \\
\hline
\end{tabular}




\begin{tabular}{|c|c|c|c|c|}
\hline Country & Banking & Currency & Sovereign & $\begin{array}{c}\text { Sovereign } \\
\text { (Restructuring) }\end{array}$ \\
\hline Swaziland & 1995 & 1985,2015 & & \\
\hline $\begin{array}{l}\text { Sweden } \\
\text { Syrian Arab }\end{array}$ & 1991,2008 & 1993 & & \\
\hline Republic & & 1988 & & \\
\hline Switzerland & 2008 & & & \\
\hline Tajikistan & & 1999,2015 & & \\
\hline Tanzania & 1987 & 1985,1990 & 1984 & 1992 \\
\hline Thailand & 1983,1997 & 1998 & & \\
\hline Togo & 1993 & 1994 & 1979 & 1997 \\
\hline $\begin{array}{l}\text { Trinidad and } \\
\text { Tobago }\end{array}$ & & 1986 & 1989 & 1989 \\
\hline Tunisia & 1991 & & & \\
\hline Turkey & 1982,2000 & $1978,1984,1991,1996,2001$ & 1978 & 1982 \\
\hline Turkmenistan & & 2008 & & \\
\hline Uganda & 1994 & 1980,1988 & 1981 & 1993 \\
\hline Ukraine & $1998,2008,2014$ & $1998,2009,2014$ & 1998,2015 & 1999,2015 \\
\hline United Kingdom & 2007 & & & \\
\hline United States & 1988,2007 & & & \\
\hline Uruguay & 1981,2002 & $1972,1983,1990,2002$ & 1983,2002 & 1991,2003 \\
\hline Uzbekistan & & 2000 & & \\
\hline Venezuela & 1994 & $1984,1989,1994,2002,2010$ & 1982,2017 & 1990 \\
\hline Vietnam & 1997 & $1972,1981,1987$ & 1985 & 1997 \\
\hline Yemen & 1996 & 1985,1995 & & \\
\hline Yugoslavia, SFR & & & 1983 & 1988 \\
\hline Zambia & 1995 & 1983, 1989, 1996, 2009, 2015 & 1983 & 1994 \\
\hline Zimbabwe & 1995 & $1983,1991,1998,2003$ & & \\
\hline
\end{tabular}


Table 2. Banking Crises Resolution and Outcomes

\begin{tabular}{|c|c|c|c|c|c|c|c|c|c|c|}
\hline \multirow[t]{2}{*}{ Country } & \multicolumn{2}{|c|}{ Crisis Dates } & \multirow{2}{*}{$\begin{array}{c}\text { Output } \\
\text { Loss }^{1 /} \\
\% \text { of } \\
\text { trend } \\
\text { GDP }\end{array}$} & \multicolumn{3}{|c|}{ Fiscal Costs ${ }^{2 /}$} & \multicolumn{2}{|c|}{ Liquidity Provision } & \multirow{2}{*}{$\begin{array}{l}\text { Peak } \\
\text { NPLs }^{4 /}\end{array}$} & \multirow{2}{*}{$\begin{array}{c}\text { Increase } \\
\text { in Public } \\
\text { Debt }^{5 /}\end{array}$} \\
\hline & Start & End & & $\begin{array}{l}\% \text { of } \\
\text { GDP }\end{array}$ & $\begin{array}{l}\text { Net, } \\
\% \text { of } \\
\text { GDP }\end{array}$ & $\begin{array}{c}\% \text { of } \\
\text { Financial } \\
\text { Sector } \\
\text { Assets }\end{array}$ & Peak $^{3 /}$ & $\begin{array}{l}\text { Liquidity } \\
\text { Support }^{3 /}\end{array}$ & & \\
\hline Albania & 1994 & 1994 & $\ldots$ & $\ldots$ & $\ldots$ & $\ldots$ & 7.6 & $\ldots$ & 26.8 & $\ldots$ \\
\hline Algeria & 1990 & $19947 /$ & 41.4 & $\ldots$ & $\ldots$ & $\ldots$ & 37.6 & 29.9 & 30.0 & 19.1 \\
\hline Argentina & 1980 & $19826 /$ & 58.2 & 55.1 & 55.1 & 213.9 & 64.6 & 62.2 & 9.0 & 33.1 \\
\hline Argentina & 1989 & 1991 & 12.6 & 6.0 & 6.0 & 21.6 & 151.6 & 135.7 & 27.0 & -21.3 \\
\hline Argentina 8/ & 1995 & 1995 & 0.0 & 2.0 & 2.0 & 8.6 & 71.4 & 63.0 & 17.0 & 8.7 \\
\hline Argentina & 2001 & 2003 & 71.0 & 9.6 & 9.6 & 28.1 & 22.9 & 22.6 & 20.1 & 81.9 \\
\hline Armenia 4/ & 1994 & $19946 /$ & $\ldots$ & $\ldots$ & $\ldots$ & $\ldots$ & 41.4 & 23.0 & $\ldots$ & $\ldots$ \\
\hline Austria & 2008 & $20127 /$ & 19.2 & 5.2 & 1.6 & 1.6 & 10.0 & 6.4 & 4.1 & 19.8 \\
\hline Azerbaijan & 1995 & $19956 /$ & $\ldots$ & ... & $\ldots$ & $\ldots$ & 127.6 & 84.5 & $\ldots$ & 0.9 \\
\hline Bangladesh & 1987 & 1987 & 0.0 & ... & $\ldots$ & $\ldots$ & 26.0 & 2.8 & 20.0 & 3.5 \\
\hline Belarus & 1995 & 1995 & $\ldots$ & $\ldots$ & $\ldots$ & $\ldots$ & 35.8 & $\ldots$ & $\ldots$ & -16.5 \\
\hline Belgium & 2008 & $20127 /$ & 15.7 & 6.2 & 0.5 & 1.6 & 13.7 & 9.7 & 4.2 & 22.2 \\
\hline Benin & 1988 & $19927 /$ & 14.9 & 17.0 & $\ldots$ & 64.3 & 99.6 & 48.6 & 80.0 & 5.7 \\
\hline Bolivia & 1986 & 1986 & 49.2 & $\ldots$ & $\ldots$ & $\ldots$ & 57.5 & 25.9 & 30.0 & -107.3 \\
\hline $\begin{array}{l}\text { Bolivia } \\
\text { Bosnia and }\end{array}$ & 1994 & 1994 & 0.0 & 6.0 & 2.7 & 15.2 & 31.9 & 12.9 & 6.2 & -19.2 \\
\hline Herzegovina & 1992 & $19967 /$ & $\ldots$ & ... & $\ldots$ & $\ldots$ & $\ldots$ & $\ldots$ & $\ldots$ & $\ldots$ \\
\hline Brazil 8/ & 1990 & $19947 /$ & 62.3 & 0.0 & 0.0 & 0.0 & 11.3 & 10.7 & $\ldots$ & -22.6 \\
\hline Brazil & 1994 & 1998 & 0.0 & 13.2 & 10.2 & 28.6 & 20.1 & 17.6 & 16.0 & -33.8 \\
\hline Bulgaria & 1996 & 1997 & 59.5 & 14.0 & 13.9 & 21.4 & 17.3 & 9.9 & 75.0 & -30.1 \\
\hline Burkina Faso & 1990 & 1994 & $\ldots$ & $\ldots$ & $\ldots$ & $\ldots$ & 9.4 & 4.5 & 16.0 & 8.9 \\
\hline Burundi & 1994 & $19987 /$ & 121.2 & $\ldots$ & $\ldots$ & $\ldots$ & 23.4 & 18.3 & 25.0 & 10.9 \\
\hline Cameroon & 1987 & $19917 /$ & 105.5 & $\ldots$ & $\ldots$ & $\ldots$ & 59.1 & 40.9 & 65.0 & 18.0 \\
\hline Cameroon & 1995 & 1997 & 8.1 & ... & $\ldots$ & $\ldots$ & 12.3 & 6.2 & 30.0 & -1.1 \\
\hline $\begin{array}{l}\text { Cape Verde } \\
\text { Central African }\end{array}$ & 1993 & 1993 & 0.0 & $\ldots$ & $\ldots$ & $\ldots$ & 4.0 & $\ldots$ & 30.0 & 18.2 \\
\hline $\begin{array}{l}\text { Rep } \\
\text { Central African }\end{array}$ & 1976 & 1976 & 0.0 & ... & $\ldots$ & $\ldots$ & 90.8 & 10.5 & $\ldots$ & -4.8 \\
\hline Rep & 1995 & 1996 & 9.0 & ... & $\ldots$ & $\ldots$ & 24.8 & 20.9 & 40.0 & -16.3 \\
\hline Chad & 1983 & 1983 & 0.0 & $\ldots$ & $\ldots$ & $\ldots$ & 199.3 & 41.3 & $\ldots$ & -7.2 \\
\hline Chad & 1992 & $19967 /$ & 0.0 & $\ldots$ & $\ldots$ & $\ldots$ & 120.9 & 41.4 & 35.0 & 27.1 \\
\hline Chile & 1976 & 1976 & 19.9 & $\ldots$ & $\ldots$ & $\ldots$ & 32.2 & 23.6 & $\ldots$ & -69.5 \\
\hline Chile & 1981 & $19857 /$ & 8.6 & 42.9 & 16.8 & 134.3 & 61.2 & 52.7 & 35.6 & 87.9 \\
\hline China, Mainland & 1998 & 1998 & 19.4 & 18.0 & $\ldots$ & 19.5 & 62.0 & 7.2 & 20.0 & 11.2 \\
\hline Colombia & 1982 & 1982 & 47.0 & 5.0 & 5.0 & 16.5 & 21.1 & 7.7 & 4.1 & 16.6 \\
\hline Colombia & 1998 & 2000 & 43.4 & 6.3 & 2.5 & 15.9 & 5.1 & 4.3 & 14.0 & 15.4 \\
\hline Congo, Dem Rep & 1983 & 1983 & 1.4 & ... & $\ldots$ & $\ldots$ & 20.0 & 18.9 & $\ldots$ & 39.5 \\
\hline Congo, Dem Rep & 1991 & $19947 /$ & 129.5 & $\ldots$ & $\ldots$ & $\ldots$ & 44.7 & 30.2 & $\ldots$ & 42.2 \\
\hline
\end{tabular}




\begin{tabular}{|c|c|c|c|c|c|c|c|c|c|c|}
\hline \multirow[t]{2}{*}{ Country } & \multicolumn{2}{|c|}{ Crisis Dates } & \multirow{2}{*}{$\begin{array}{l}\text { Output } \\
\text { Loss }{ }^{1 /} \\
\% \text { of } \\
\text { trend } \\
\text { GDP }\end{array}$} & \multicolumn{3}{|c|}{ Fiscal Costs $^{2 /}$} & \multicolumn{2}{|c|}{ Liquidity Provision } & \multirow{2}{*}{$\begin{array}{c}\text { Peak } \\
\text { NPLs }^{4 /}\end{array}$} & \multirow{2}{*}{$\begin{array}{l}\text { Increase } \\
\text { in Public } \\
\text { Debt }^{5 /}\end{array}$} \\
\hline & Start & End & & $\begin{array}{l}\% \text { of } \\
\text { GDP }\end{array}$ & $\begin{array}{l}\text { Net, } \\
\% \text { of } \\
\text { GDP }\end{array}$ & $\begin{array}{c}\% \text { of } \\
\text { Financial } \\
\text { Sector } \\
\text { Assets }\end{array}$ & Peak $^{3 /}$ & $\begin{array}{l}\text { Liquidity } \\
\text { Support }^{3 /}\end{array}$ & & \\
\hline Congo, Dem Rep & 1994 & $19987 /$ & 79.0 & $\ldots$ & $\ldots$ & $\ldots$ & 77.3 & 77.1 & 75.0 & 39.3 \\
\hline Congo, Rep & 1992 & 1994 & 47.4 & ... & $\ldots$ & $\ldots$ & 30.7 & 16.6 & $\ldots$ & 103.5 \\
\hline Costa Rica & 1987 & 1991 & 0.0 & $\ldots$ & $\ldots$ & $\ldots$ & 20.2 & 6.1 & $\ldots$ & -27.5 \\
\hline Costa Rica & 1994 & 1995 & 0.0 & $\ldots$ & $\ldots$ & $\ldots$ & 15.2 & 6.3 & 32.0 & 4.8 \\
\hline Cote d'Ivoire & 1988 & $19927 /$ & 45.0 & 25.0 & 25.0 & 63.6 & 76.9 & 22.5 & 50.0 & 13.6 \\
\hline Croatia & 1998 & 1999 & $\ldots$ & 6.9 & 6.9 & 15.0 & 3.2 & 3.1 & 10.5 & 14.1 \\
\hline Czech Republic 8/ & 1996 & $20007 /$ & $\cdots$ & 6.8 & 5.8 & 9.6 & 12.7 & 4.2 & 18.0 & 1.8 \\
\hline Cyprus & 2011 & $20157 /$ & 76.5 & 18.0 & 18.0 & 2.6 & 20.3 & 14.1 & 47.8 & 21.3 \\
\hline Denmark & 2008 & 2009 & 35.0 & 5.9 & 2.4 & 3.1 & 17.7 & 9.7 & 5.95 & 32.8 \\
\hline Djibouti & 1991 & $19957 /$ & 42.6 & $\ldots$ & $\ldots$ & $\ldots$ & 5.2 & 3.2 & $\ldots$ & ... \\
\hline Dominican Rep & 2003 & 2004 & 12.5 & 22.0 & 20.8 & 63.7 & 43.4 & 38.1 & 9.0 & 16.5 \\
\hline Ecuador & 1982 & $19867 /$ & 98.2 & ... & $\ldots$ & ... & 146.7 & 100.0 & $\ldots$ & 24.4 \\
\hline Ecuador & 1998 & 2002 & 25.4 & 21.7 & 16.3 & 76.8 & 26.0 & 22.5 & 40.0 & 9.1 \\
\hline Egypt & 1980 & 1980 & 0.9 & $\ldots$ & $\ldots$ & $\ldots$ & 66.7 & 22.7 & $\ldots$ & -4.2 \\
\hline El Salvador & 1989 & 1990 & 0.0 & $\ldots$ & $\ldots$ & $\ldots$ & 51.6 & 11.5 & 37.0 & -29.6 \\
\hline Equatorial Guinea & 1983 & $19836 /$ & 0.0 & $\ldots$ & $\ldots$ & $\ldots$ & 75.8 & $\ldots$ & $\ldots$ & ... \\
\hline Eritrea & 1993 & 1993 6/ & $\cdots$ & $\ldots$ & $\ldots$ & $\cdots$ & $\cdots$ & $\cdots$ & $\cdots$ & ... \\
\hline Estonia & 1992 & 1994 & $\ldots$ & 1.9 & 1.6 & $\ldots$ & 30.9 & $\ldots$ & 7.0 & ... \\
\hline Finland & 1991 & 1995 & 69.6 & 12.8 & 11.1 & 15.5 & 12.0 & 5.5 & 13.0 & 43.6 \\
\hline France 8/ & 2008 & 2009 & 23.3 & 1.3 & 1.1 & 0.3 & 9.6 & 8.2 & 4.5 & 15.9 \\
\hline Georgia & 1991 & $19957 /$ & $\ldots$ & $\ldots$ & $\ldots$ & $\ldots$ & $\ldots$ & $\ldots$ & 33.0 & ... \\
\hline Germany & 2008 & 2009 & 12.3 & 2.7 & 0.7 & 0.9 & 12.9 & 4.0 & 3.7 & 16.2 \\
\hline Ghana & 1982 & 1983 & 45.3 & 6.0 & 6.0 & 105.8 & 0.2 & 0.1 & 35.0 & 15.5 \\
\hline Greece & 2008 & $20127 /$ & 64.9 & 28.7 & 17.1 & 17.1 & 61.7 & 59.8 & 37.1 & 43.9 \\
\hline Guinea & 1985 & $19856 /$ & 0.0 & 3.0 & $\ldots$ & $\ldots$ & $\ldots$ & $\ldots$ & $\ldots$ & ... \\
\hline Guinea & 1993 & 1993 & 0.0 & ... & $\ldots$ & $\ldots$ & 14.6 & 3.9 & 45.0 & 6.7 \\
\hline Guinea-Bissau & 1995 & 1998 & 29.6 & $\ldots$ & $\ldots$ & $\ldots$ & 137.3 & 39.2 & 45.0 & 108.1 \\
\hline Guinea-Bissau & 2014 & ongoing & 0.0 & $\cdots$ & $\ldots$ & $\ldots$ & 33.4 & 22.4 & 25.7 & 3.2 \\
\hline Guyana & 1993 & 1993 & 0.0 & ... & $\ldots$ & $\ldots$ & 1.8 & 1.7 & $\ldots$ & -241.0 \\
\hline Haiti & 1994 & 1998 & 37.5 & $\cdots$ & $\ldots$ & $\ldots$ & 4.8 & $\ldots$ & $\ldots$ & -119.4 \\
\hline Hungary & 1991 & $19957 /$ & 0.0 & 10.0 & $\ldots$ & 21.3 & 47.0 & 4.6 & 23.0 & 19.6 \\
\hline Hungary $8 /$ & 2008 & $20127 /$ & 37.3 & 2.9 & 0.1 & 4.1 & 2.3 & 2.2 & 17.3 & 3.8 \\
\hline Iceland & 2008 & $20127 /$ & 34.5 & 37.6 & 3.3 & 14.3 & 33.8 & 28.1 & 61.2 & 67.9 \\
\hline India & 1993 & 1993 & 0.0 & $\ldots$ & $\ldots$ & $\ldots$ & 4.3 & 3.6 & 20.0 & -7.7 \\
\hline Indonesia & 1997 & $20017 /$ & 69.0 & 56.8 & 52.2 & 105.4 & 23.1 & 17.2 & 32.5 & 67.6 \\
\hline Ireland & 2008 & $20127 /$ & 107.7 & 37.6 & 26.8 & 4.5 & 18.1 & 15.4 & 25.7 & 76.5 \\
\hline Israel & 1983 & 1986 & 42.7 & 30.0 & $\ldots$ & 30.9 & 5.3 &. & $\ldots$ & \\
\hline
\end{tabular}




\begin{tabular}{|c|c|c|c|c|c|c|c|c|c|c|}
\hline \multirow[t]{2}{*}{ Country } & \multicolumn{2}{|c|}{ Crisis Dates } & \multirow{2}{*}{$\begin{array}{l}\text { Output } \\
\text { Loss }^{1 /} \\
\% \text { of } \\
\text { trend } \\
\text { GDP }\end{array}$} & \multicolumn{3}{|c|}{ Fiscal Costs ${ }^{2 /}$} & \multicolumn{2}{|c|}{ Liquidity Provision } & \multirow{2}{*}{$\begin{array}{c}\text { Peak } \\
\text { NPLs }^{4 /}\end{array}$} & \multirow{2}{*}{$\begin{array}{c}\text { Increase } \\
\text { in Public } \\
\text { Debt }^{5 /}\end{array}$} \\
\hline & Start & End & & $\begin{array}{l}\% \text { of } \\
\text { GDP }\end{array}$ & $\begin{array}{l}\text { Net, } \\
\% \text { of } \\
\text { GDP }\end{array}$ & $\begin{array}{c}\% \text { of } \\
\text { Financial } \\
\text { Sector } \\
\text { Assets }\end{array}$ & Peak $^{3 /}$ & $\begin{array}{l}\text { Liquidity } \\
\text { Support }^{3 /}\end{array}$ & & \\
\hline Italy & 2008 & 2009 & 32.2 & 0.7 & 0.7 & 0.3 & 19.4 & 17.8 & 18.0 & 8.6 \\
\hline Jamaica & 1996 & 1998 & 37.8 & 43.9 & 39.0 & 161.4 & 0.4 & 0.3 & 28.9 & 2.9 \\
\hline Japan & 1997 & $20017 /$ & 45.0 & 8.6 & 8.5 & 3.2 & 2.4 & 1.6 & 35.0 & 41.7 \\
\hline Jordan & 1989 & 1991 & 106.4 & 10.0 & $\ldots$ & 12.5 & 20.7 & 16.1 & $\ldots$ & -61.0 \\
\hline Kazakhstan 8/ & 2008 & 2008 & 0.0 & 3.7 & 3.7 & 7.5 & 6.6 & 5.3 & 37.7 & 6.5 \\
\hline Kenya & 1985 & 1985 & 23.7 & $\ldots$ & $\ldots$ & $\ldots$ & 2.0 & 1.9 & $\ldots$ & 11.0 \\
\hline Kenya & 1992 & 1994 & 50.3 & $\ldots$ & $\ldots$ & $\ldots$ & 25.2 & 24.3 & $\ldots$ & 12.1 \\
\hline Korea & 1997 & 1998 & 57.6 & 31.2 & 23.2 & 57.2 & 27.4 & 11.9 & 35.0 & 9.9 \\
\hline Kuwait & 1982 & 1985 & 143.4 & $\ldots$ & $\ldots$ & $\ldots$ & 9.6 & 2.9 & 40.0 & 16.2 \\
\hline Kyrgyz Rep & 1995 & $19997 /$ & $\ldots$ & $\ldots$ & $\ldots$ & $\ldots$ & 286.1 & 51.8 & 85.0 & 42.9 \\
\hline Latvia & 1995 & 1996 & $\ldots$ & 3.0 & 3.0 & 10.1 & 9.2 & 5.5 & 20.0 & 0.4 \\
\hline Latvia & 2008 & $20127 /$ & 93.9 & 8.1 & 3.9 & 11.0 & 3.6 & 3.4 & 15.9 & 27.6 \\
\hline Lebanon & 1990 & 1993 & 102.2 & $\ldots$ & $\ldots$ & $\ldots$ & 4.4 & 2.8 & $\ldots$ & ... \\
\hline Liberia & 1991 & $19957 /$ & $\ldots$ & $\ldots$ & $\ldots$ & $\ldots$ & 85.2 & 84.2 & $\ldots$ & $\ldots$ \\
\hline Lithuania & 1995 & 1996 & $\ldots$ & 3.1 & 2.9 & 18.8 & 27.5 & 18.9 & 32.2 & 10.8 \\
\hline Luxembourg & 2008 & $20127 /$ & 43.3 & 7.2 & 5.0 & 0.2 & 6.0 & 1.1 & 1.7 & 12.7 \\
\hline Macedonia, FYR & 1993 & 1995 & 0.0 & 32.0 & $\ldots$ & $\ldots$ & 22.3 & $\ldots$ & 70.0 & $\ldots$ \\
\hline Madagascar & 1988 & 1988 & 0.0 & $\ldots$ & $\ldots$ & $\ldots$ & 20.2 & 19.4 & 25.0 & -25.8 \\
\hline Malaysia & 1997 & 1999 & 31.4 & 16.4 & 5.1 & 12.7 & 9.7 & 8.8 & 30.0 & 0.2 \\
\hline Mali & 1987 & $19917 /$ & 0.0 & $\ldots$ & $\ldots$ & $\ldots$ & 50.5 & 14.8 & 75.0 & -11.3 \\
\hline Mauritania & 1984 & 1984 & 7.5 & 15.0 & $\ldots$ & 53.2 & 48.4 & 27.7 & 70.0 & $\ldots$ \\
\hline Mexico & 1981 & $19857 /$ & 26.6 & $\ldots$ & $\ldots$ & $\ldots$ & 5.3 & 2.6 & $\ldots$ & 22.6 \\
\hline Mexico & 1994 & 1996 & 13.7 & 19.3 & 18.0 & 54.9 & 16.8 & 15.8 & 18.9 & 16.4 \\
\hline Moldova & 2014 & ongoing & & 11.7 & 11.7 & 26.1 & 24.7 & 24.0 & 16.4 & 19.5 \\
\hline Mongolia & 2008 & 2009 & 0.0 & 5.1 & 5.1 & 15.3 & 34.5 & 33.2 & 20.0 & -5.0 \\
\hline Morocco & 1980 & $19847 /$ & 21.9 & $\ldots$ & $\ldots$ & $\ldots$ & 22.1 & 8.6 & $\ldots$ & 35.6 \\
\hline Mozambique & 1987 & $19917 /$ & 0.0 & $\ldots$ & $\ldots$ & $\ldots$ & 4.2 & 4.2 & $\ldots$ & 60.9 \\
\hline Nepal & 1988 & 1988 & 0.0 & $\ldots$ & $\ldots$ & $\ldots$ & 14.6 & 3.8 & 29.0 & 11.7 \\
\hline Netherlands & 2008 & 2009 & 26.1 & 14.3 & 5.1 & 4.0 & 5.5 & 3.5 & 3.2 & 24.9 \\
\hline Nicaragua & 1990 & 1993 & 11.4 & $\ldots$ & $\ldots$ & $\ldots$ & 195.1 & 156.5 & 50.0 & -31.0 \\
\hline Nicaragua & 2000 & 2001 & 0.0 & 13.6 & 12.6 & 45.7 & 21.8 & 20.9 & 12.7 & 14.9 \\
\hline Niger & 1983 & 1985 & 97.2 & $\ldots$ & $\ldots$ & $\ldots$ & 45.6 & 14.1 & 50.0 & 25.9 \\
\hline Nigeria & 1991 & $19957 /$ & 0.0 & $\ldots$ & $\ldots$ & $\ldots$ & 6.6 & 5.4 & 77.0 & 63.3 \\
\hline Nigeria & 2009 & 2012 & 14.0 & 11.8 & 11.8 & 32.2 & 49.6 & 32.9 & 30.1 & 8.4 \\
\hline Norway & 1991 & 1993 & 5.1 & 2.7 & 0.6 & 2.8 & 16.9 & 4.2 & 16.4 & 19.2 \\
\hline Panama & 1988 & 1989 & 85.0 & 12.9 & $\ldots$ & 24.4 & 3.6 & 3.2 & $\ldots$ & -2.6 \\
\hline Paraguay & 1995 & 1995 & 15.3 & 12.9 & 10.0 & 54.9 & 27.3 & 23.8 & 8.1 & -1.2 \\
\hline
\end{tabular}




\begin{tabular}{|c|c|c|c|c|c|c|c|c|c|c|}
\hline \multirow[t]{2}{*}{ Country } & \multicolumn{2}{|c|}{ Crisis Dates } & \multirow{2}{*}{$\begin{array}{l}\text { Output } \\
\text { Loss }^{1 /} \\
\% \text { of } \\
\text { trend } \\
\text { GDP }\end{array}$} & \multicolumn{3}{|c|}{ Fiscal Costs ${ }^{2 /}$} & \multicolumn{2}{|c|}{ Liquidity Provision } & \multirow{2}{*}{$\begin{array}{c}\text { Peak } \\
\text { NPLs }^{4 /}\end{array}$} & \multirow{2}{*}{$\begin{array}{c}\text { Increase } \\
\text { in Public } \\
\text { Debt }^{5 /}\end{array}$} \\
\hline & Start & End & & $\begin{array}{l}\% \text { of } \\
\text { GDP }\end{array}$ & $\begin{array}{l}\text { Net, } \\
\% \text { of } \\
\text { GDP }\end{array}$ & $\begin{array}{c}\% \text { of } \\
\text { Financial } \\
\text { Sector } \\
\text { Assets }\end{array}$ & Peak $^{3 /}$ & $\begin{array}{l}\text { Liquidity } \\
\text { Support }^{3 /}\end{array}$ & & \\
\hline Peru & 1983 & 1983 6/ & 55.2 & $\ldots$ & $\ldots$ & $\ldots$ & 16.8 & 9.7 & $\ldots$ & 14.3 \\
\hline Philippines & 1983 & 1986 & 91.7 & 3.0 & $\ldots$ & 5.9 & 19.4 & 1.5 & 19.0 & 44.8 \\
\hline Philippines & 1997 & $20017 /$ & 0.0 & 13.2 & 13.2 & 22.5 & 1.4 & 0.7 & 20.0 & 10.4 \\
\hline Poland & 1992 & 1994 & 0.0 & 3.5 & $\ldots$ & 13.7 & 45.9 & 8.7 & 24.0 & -21.6 \\
\hline Portugal & 2008 & $20127 /$ & 35.0 & 11.1 & 7.6 & 4.4 & 25.7 & 24.7 & 12.9 & 38.5 \\
\hline Romania & 1998 & $19996 /$ & 0.0 & 6.5 & $\ldots$ & 34.3 & 129.1 & $\ldots$ & 30.0 & $\ldots$ \\
\hline Russia & 1998 & $19986 /$ & $\ldots$ & 6.0 & 6.0 & 0.3 & 23.7 & 21.1 & 40.0 & -7.1 \\
\hline $\begin{array}{l}\text { Russia 8/ } \\
\text { São Tomé \& }\end{array}$ & 2008 & 2009 & 0.0 & 2.3 & 2.3 & 6.4 & 24.2 & 23.3 & 9.6 & 6.1 \\
\hline Príncipe & 1992 & 1992 6/ & 1.9 & $\ldots$ & $\ldots$ & $\ldots$ & $\ldots$ & $\ldots$ & 90.0 & -706.3 \\
\hline Senegal & 1988 & 1991 & 5.6 & 17.0 & $\ldots$ & 64.2 & 74.7 & 6.6 & 50.0 & -14.2 \\
\hline Sierra Leone & 1990 & $19947 /$ & 34.5 & $\ldots$ & $\ldots$ & $\ldots$ & 0.0 & 0.0 & 45.0 & 62.9 \\
\hline Slovak Rep & 1998 & $20027 /$ & 0.0 & $\ldots$ & $\ldots$ & $\ldots$ & 13.0 & 4.8 & 35.0 & 15.4 \\
\hline Slovenia & 1992 & 1992 & $\ldots$ & 14.6 & $\ldots$ & 38.1 & 10.0 & $\ldots$ & 3.6 & ... \\
\hline Slovenia & 2008 & $20127 /$ & 39.1 & 9.9 & 8.4 & 8.0 & 14.2 & 14.0 & 18.0 & 20.9 \\
\hline Spain & 1977 & $19817 /$ & 58.5 & 7.7 & $\ldots$ & 8.6 & 7.6 & 3.5 & 5.8 & 3.8 \\
\hline Spain & 2008 & $20127 /$ & 38.8 & 5.4 & 4.8 & 2.0 & 33.5 & 31.3 & 9.4 & 31.8 \\
\hline Sri Lanka & 1989 & 1991 & 19.6 & 5.0 & 5.0 & 22.0 & 8.0 & 2.0 & 35.0 & -5.5 \\
\hline Swaziland & 1995 & $19997 /$ & 45.7 & $\ldots$ & $\ldots$ & $\ldots$ & 3.6 & 3.2 & $\ldots$ & 2.5 \\
\hline Sweden & 1991 & 1995 & 32.9 & 3.6 & 0.2 & 3.0 & 3.1 & 0.2 & 13.0 & 36.2 \\
\hline Sweden 8/ & 2008 & 2009 & 25.5 & 0.2 & 0.0 & 0.2 & 11.1 & 11.0 & 2.0 & 12.8 \\
\hline Switzerland 8/ & 2008 & 2009 & 0.0 & 1.1 & -0.4 & 0.7 & 4.6 & 3.3 & 0.5 & 1.6 \\
\hline Tanzania & 1987 & 1988 & 0.0 & 10.0 & $\ldots$ & 53.9 & 100.9 & 97.6 & 70.0 & 64.6 \\
\hline Thailand & 1983 & 1983 & 24.8 & 0.7 & $\ldots$ & 1.3 & 8.5 & 2.0 & $\ldots$ & 15.7 \\
\hline Thailand & 1997 & 2000 & 109.3 & 43.8 & 34.8 & 30.6 & 5.1 & 4.4 & 33.0 & 42.1 \\
\hline Togo & 1993 & 1994 & 38.8 & $\ldots$ & $\ldots$ & $\ldots$ & 6.2 & 1.7 & $\ldots$ & 23.8 \\
\hline Tunisia & 1991 & 1991 & 1.3 & 3.0 & $\ldots$ & 5.0 & 31.5 & 15.1 & $\ldots$ & 4.2 \\
\hline Turkey & 1982 & 1984 & 35.0 & 2.5 & $\ldots$ & 11.7 & 71.7 & 29.3 & $\ldots$ & 12.3 \\
\hline Turkey & 2000 & 2001 & 37.6 & 32.0 & 30.7 & 107.2 & 20.5 & 15.2 & 27.6 & 15.3 \\
\hline Uganda & 1994 & 1994 & 0.0 & $\ldots$ & $\ldots$ & $\ldots$ & 7.6 & 3.9 & $\ldots$ & -26.9 \\
\hline Ukraine & 1998 & 1999 & 0.0 & 0.0 & 0.0 & 0.0 & 19.1 & 3.3 & 62.4 & 6.0 \\
\hline Ukraine & 2008 & 2010 & 0.0 & 4.5 & 4.5 & 10.1 & 16.4 & 15.8 & 15.5 & 26.5 \\
\hline Ukraine & 2014 & ongoing & 93.2 & 13.9 & 13.9 & 17.2 & 14.0 & 4.4 & 55.1 & 53.4 \\
\hline United Kingdom & 2007 & $20117 /$ & 25.3 & 8.8 & 3.8 & 5.8 & 3.4 & 2.5 & 4.0 & 27.0 \\
\hline United States 8/ & 1988 & 1988 & 0.0 & 3.7 & $\ldots$ & 2.7 & 0.1 & 0.1 & 4.1 & 10.5 \\
\hline United States & 2007 & 2011 & 30.0 & 4.5 & 0.6 & 2.2 & 4.7 & 4.7 & 5.0 & 21.9 \\
\hline Uruguay & 1981 & $19857 /$ & 38.1 & 31.2 & $\ldots$ & 101.2 & 24.6 & 18.5 & $\ldots$ & 83.3 \\
\hline Uruguay & 2002 & 2005 & 66.1 & 20.0 & 10.8 & 35.7 & 12.8 & 7.9 & 36.3 & 37.0 \\
\hline
\end{tabular}




\begin{tabular}{|c|c|c|c|c|c|c|c|c|c|c|}
\hline \multirow[t]{2}{*}{ Country } & \multicolumn{2}{|c|}{ Crisis Dates } & \multirow{2}{*}{$\begin{array}{l}\text { Output } \\
\text { Loss }^{1 /} \\
\% \text { of } \\
\text { trend } \\
\text { GDP }\end{array}$} & \multicolumn{3}{|c|}{ Fiscal Costs ${ }^{2 /}$} & \multicolumn{2}{|c|}{ Liquidity Provision } & \multirow[t]{2}{*}{$\begin{array}{c}\text { Peak } \\
\text { NPLs }^{4 /}\end{array}$} & \multirow{2}{*}{$\begin{array}{l}\text { Increase } \\
\text { in Public } \\
\text { Debt }^{5 /}\end{array}$} \\
\hline & Start & End & & $\begin{array}{l}\% \text { of } \\
\text { GDP }\end{array}$ & $\begin{array}{l}\text { Net, } \\
\% \text { of } \\
\text { GDP }\end{array}$ & $\begin{array}{c}\% \text { of } \\
\text { Financial } \\
\text { Sector } \\
\text { Assets }\end{array}$ & Peak $^{3 /}$ & $\begin{array}{l}\text { Liquidity } \\
\text { Support }^{3 /}\end{array}$ & & \\
\hline Venezuela & 1994 & $19987 /$ & 1.2 & 15.0 & 12.5 & 60.8 & 2.9 & 1.6 & 24.0 & -23.0 \\
\hline Vietnam & 1997 & 1997 & 0.0 & 10.0 & 10.0 & 54.3 & 64.9 & 24.8 & 35.0 & -52.7 \\
\hline Yemen & 1996 & 1996 & 16.4 & $\ldots$ & $\ldots$ & $\ldots$ & 0.8 & 0.7 & $\ldots$ & -56.7 \\
\hline Zambia & 1995 & 1998 & 31.1 & 1.4 & $\ldots$ & 14.7 & 27.9 & 24.9 & $\ldots$ & 36.2 \\
\hline Zimbabwe & 1995 & $19997 /$ & 10.4 & $\ldots$ & $\ldots$ & $\ldots$ & 8.6 & 5.0 & $\ldots$ & 20.9 \\
\hline
\end{tabular}

1/ In percent of GDP. Output losses are computed as the cumulative sum of the differences between actual and trend real GDP over the period [T, $\mathrm{T}+3]$, expressed in percent of trend real GDP, with T denoting the starting year of the crisis. The trend is computed by applying an HP filter $(\lambda=100)$ to the GDP series over [T-20, T-1]. No output losses are reported for crises in transition economies that took place during the period of transition to market economies.

2/ Fiscal costs refer to outlays directly related to the restructuring of the financial sector.

3/ Liquidity is measured as the ratio of central bank claims on deposit money banks (line 12 in IFS) and liquidity support from the Treasury to total deposits and liabilities to non-residents. Total deposits are computed as the sum of demand deposits (line 24), other deposits (line 25), and liabilities to non-residents (line 26).

4/ In percent of total loans.

5/ In percent of GDP. For episodes starting in 2007 and later, the increase in public debt is measured as the change in debt projections, over [T-1, $\mathrm{T}+3$ ], relative to the pre-crisis debt projections, where $\mathrm{T}$ is the starting year of the crisis.

6/ Credit data missing. For these countries, end dates are based on GDP growth only.

$7 /$ We truncate the duration of crises at 5 years, starting with the first crisis year.

$8 /$ Borderline cases.

Source: WEO, IFS, IMF Staff reports, IMF Financial Soundness Indicators, Laeven and Valencia (2013), and authors' calculation.

\section{CInternational Monetary Fund. Not for Redistribution}


Table 3. Banking Crisis Policy Responses

\begin{tabular}{|c|c|c|c|c|c|c|c|c|c|c|c|c|}
\hline \multirow[t]{3}{*}{ Country } & \multirow[t]{3}{*}{ Start 1/ } & \multicolumn{2}{|c|}{ Deposit Freeze } & \multicolumn{2}{|c|}{ Bank Holiday } & \multicolumn{3}{|c|}{ Guarantees on Bank Liabilities } & \multirow[t]{3}{*}{$\begin{array}{c}\text { Bank } \\
\text { Nationalization }\end{array}$} & \multirow[t]{3}{*}{$\begin{array}{c}\text { Asset } \\
\text { Purchase }\end{array}$} & \multirow{3}{*}{$\begin{array}{c}\text { Bank } \\
\text { Recapitalization } \\
\begin{array}{c}\text { In percent of } \\
\text { GDP }\end{array}\end{array}$} & \multirow[t]{2}{*}{$\begin{array}{c}\text { IMF } \\
\text { Program }\end{array}$} \\
\hline & & Date & Duration & Date & Duration & Start & Duration & Coverage & & & & \\
\hline & & & (in months) & & (in days) & & (in months) & & & & & \\
\hline Argentina & Mar-80 & & & & & & & & $\mathrm{Y}$ & $\mathrm{N}$ & & 1983 \\
\hline Argentina & Dec-89 & $\begin{array}{c}\text { 28-Dec- } \\
1989\end{array}$ & 120 & 1-Jan-1990 & 4 & & & & $\mathrm{~N}$ & $\mathrm{~N}$ & & 1990 \\
\hline Argentina & Jan-95 & & & & & & & & $\mathrm{N}$ & $\mathrm{N}$ & 0.28 & 1995 \\
\hline Argentina & Nov-01 & 3-Dec-2001 & 12 & $\begin{array}{l}\text { 31-Dec- } \\
2001\end{array}$ & 5 & & & & $\mathrm{Y}$ & $\mathrm{N}$ & 9.58 & 2000 \\
\hline Austria & Sep-08 & & & & & Dec-08 & & $\begin{array}{c}\text { Unlimited } \\
\text { coverage to } \\
\text { depositors, } \\
\text { bank and } \\
\text { non-bank } \\
\text { bonds. }\end{array}$ & Y & $\mathrm{N}$ & 3.96 & \\
\hline Belgium & Sep-08 & & & & & Oct-08 & & 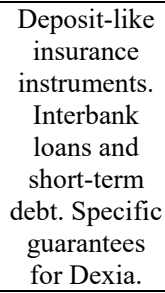 & $\mathrm{Y}$ & $\mathrm{N}$ & 5.80 & \\
\hline Bolivia & Nov-94 & & & & & & & & $\mathrm{N}$ & $\mathrm{Y}$ & 0.95 & \\
\hline Brazil & Feb-90 & 1-Mar-1990 & 29 & & & & & & $\mathrm{~N}$ & $\mathrm{~N}$ & 0.00 & 1989 \\
\hline Brazil & Dec-94 & & & & & & & & $\mathrm{N}$ & $\mathrm{N}$ & 4.98 & \\
\hline Bulgaria & Jan-96 & & & & & & & & $\mathrm{Y}$ & $\mathrm{Y}$ & 2.31 & 1996 \\
\hline Chile & Nov-81 & & & & & & & & $\mathrm{N}$ & $\bar{Y}$ & 34.33 & 1983 \\
\hline Colombia & Jul-82 & & & & & & & & $\mathrm{Y}$ & $\mathrm{N}$ & 1.87 & \\
\hline Colombia & Jun-98 & & & & & & & & $\mathrm{Y}$ & $\mathrm{Y}$ & 4.26 & \\
\hline Cote d'Ivoire & 1988 & & & & & & & & $\mathrm{~N}$ & $\mathrm{Y}$ & small & 1985 \\
\hline Croatia & Mar-98 & & & & & & & & $\mathrm{Y}$ & $\mathrm{Y}$ & 3.20 & \\
\hline
\end{tabular}




\begin{tabular}{|c|c|c|c|c|c|c|c|c|c|c|c|c|}
\hline \multirow[t]{3}{*}{ Country } & \multirow[t]{3}{*}{ Start $1 /$} & \multicolumn{2}{|c|}{ Deposit Freeze } & \multicolumn{2}{|c|}{ Bank Holiday } & \multicolumn{3}{|c|}{ Guarantees on Bank Liabilities } & \multirow[t]{3}{*}{$\begin{array}{c}\text { Bank } \\
\text { Nationalization }\end{array}$} & \multirow{3}{*}{$\begin{array}{c}\text { Asset } \\
\text { Purchase }\end{array}$} & \multirow{3}{*}{$\begin{array}{c}\text { Bank } \\
\text { Recapitalization } \\
\begin{array}{c}\text { In percent of } \\
\text { GDP }\end{array}\end{array}$} & \multirow{2}{*}{$\begin{array}{c}\text { IMF } \\
\text { Program }\end{array}$} \\
\hline & & Date & Duration & Date & Duration & Start & Duration & Coverage & & & & \\
\hline & & & (in months) & & (in days) & & (in months) & & & & & \\
\hline $\begin{array}{l}\text { Czech } \\
\text { Republic }\end{array}$ & Jun-96 & & & & & Jun-96 & 18 & $\begin{array}{c}\text { Depositors, } \\
\text { except } \\
\text { shareholders } \\
\text { up to CZK4m } \\
\text { (at the } 18 \\
\text { banks under } \\
\text { restructuring) } \\
\text { and CZK0 } \\
1 \mathrm{~m} \\
\text { everywhere } \\
\text { else }\end{array}$ & $\mathrm{N}$ & $\mathrm{Y}$ & 0.98 & \\
\hline Cyprus & Jun-11 & $\begin{array}{l}\text { 28-Mar- } \\
2013\end{array}$ & 14 & $\begin{array}{l}\text { 18-Mar- } \\
2013\end{array}$ & 8 & & & & $\mathrm{Y}$ & $\mathrm{Y}$ & 18.90 & 2013 \\
\hline Denmark & Sep-08 & & & & & Feb-09 & & $\begin{array}{c}\text { Deposits and } \\
\text { unsecured } \\
\text { claims of } \\
\text { PCA banks. }\end{array}$ & $\bar{Y}$ & $\mathrm{~N}$ & 2.80 & \\
\hline $\begin{array}{l}\text { Dominican } \\
\text { Republic }\end{array}$ & Apr-03 & & & & & & & & $\mathrm{N}$ & $\mathrm{Y}$ & 0.00 & 2004 \\
\hline Ecuador & Aug-98 & $\begin{array}{l}\text { 12-Mar- } \\
1999\end{array}$ & 6 & 8-Mar-1999 & 5 & Dec-98 & 37 & $\begin{array}{c}\text { All creditors } \\
\text { except for } \\
\text { subordinated } \\
\text { debt and } \\
\text { related parties }\end{array}$ & $\mathrm{Y}$ & $\mathrm{Y}$ & 1.90 & 2000 \\
\hline Estonia & Nov-92 & & & & & & & & $\mathrm{Y}$ & $\mathrm{Y}$ & 1.26 & 1993 \\
\hline Finland & Sep-91 & & & & & Feb-93 & 70 & $\begin{array}{l}\text { All creditors } \\
\text { except for } \\
\text { shareholders }\end{array}$ & $\mathrm{Y}$ & $\mathrm{Y}$ & 8.63 & \\
\hline France & Sep-08 & & & & & Oct-08 & & & $\mathrm{N}$ & $\mathrm{N}$ & 1.00 & \\
\hline Germany & Sep-08 & & & & & Oct-08 & & $\begin{array}{l}\text { Unlimited } \\
\text { coverage of } \\
\text { household } \\
\text { deposits. }\end{array}$ & $\mathrm{Y}$ & $\mathrm{Y}$ & 1.80 & \\
\hline Ghana & Jan-82 & & & & & & & & $\mathrm{N}$ & $\mathrm{Y}$ & 6.00 & \\
\hline Greece & Sep-08 & 20-Jul-2015 & ongoing & 29-Jun-2015 & 21 & Oct-08 & & & $\mathrm{N}$ & $\mathrm{Y}$ & 25.40 & $\begin{array}{l}2010, \\
2012\end{array}$ \\
\hline Hungary & Sep-08 & & & & & Oct-08 & & $\begin{array}{l}\text { Unlimited } \\
\text { protection to }\end{array}$ & $\mathrm{N}$ & $\mathrm{N}$ & 0.23 & 2008 \\
\hline
\end{tabular}




\begin{tabular}{|c|c|c|c|c|c|c|c|c|c|c|c|c|}
\hline \multirow[t]{2}{*}{ Country } & \multirow[t]{2}{*}{ Start 1/ } & \multicolumn{2}{|c|}{ Deposit Freeze } & \multicolumn{2}{|c|}{ Bank Holiday } & \multicolumn{3}{|c|}{ Guarantees on Bank Liabilities } & \multirow{3}{*}{$\begin{array}{c}\text { Bank } \\
\text { Nationalization }\end{array}$} & \multirow{3}{*}{$\begin{array}{c}\text { Asset } \\
\text { Purchase }\end{array}$} & \multirow{3}{*}{$\begin{array}{c}\text { Bank } \\
\text { Recapitalization } \\
\begin{array}{c}\text { In percent of } \\
\text { GDP }\end{array}\end{array}$} & \multirow{2}{*}{$\begin{array}{c}\text { IMF } \\
\text { Program }\end{array}$} \\
\hline & & Date & Duration & Date & Duration & Start & Duration & Coverage & & & & \\
\hline & & & (in months) & & (in days) & & (in months) & & & & & \\
\hline & & & & & & & & $\begin{array}{l}\text { depositors of } \\
\text { small banks. }\end{array}$ & & & & \\
\hline Iceland & Sep-08 & & & & & Oct-08 & & $\begin{array}{l}\text { Unlimited } \\
\text { coverage to } \\
\text { domestic } \\
\text { deposits. } \\
\end{array}$ & $\mathrm{Y}$ & $\mathrm{N}$ & 24.30 & 2008 \\
\hline Indonesia & Nov-97 & & & & & $\begin{array}{l}\text { Jan-98 } \\
\end{array}$ & 78 & $\begin{array}{c}\text { All liabilities } \\
\text { of domestic } \\
\text { banks } \\
\text { (excluding } \\
\text { shareholders' } \\
\text { capital, } \\
\text { subordinated } \\
\text { debt, and } \\
\text { related- } \\
\text { parties } \\
\text { deposits). }\end{array}$ & $\mathrm{Y}$ & $\bar{Y}$ & 37.30 & 1998 \\
\hline Ireland & Sep-08 & & & & & $\begin{array}{l}\text { Sep-08 } \\
\text { Se }\end{array}$ & & $\begin{array}{c}\text { Unlimited } \\
\text { coverage to } \\
\text { most } \\
\text { liabilities of } \\
10 \text { banks. }\end{array}$ & $\mathrm{Y}$ & $\bar{Y}$ & 37.13 & 2010 \\
\hline Italy & Sep-08 & & & & & $\begin{array}{l}\text { Nov- } \\
08\end{array}$ & & $\begin{array}{c}\text { State } \\
\text { guarantee for } \\
\text { new bank } \\
\text { liabilities. }\end{array}$ & $\mathrm{N}$ & $\mathrm{N}$ & 0.30 & \\
\hline Jamaica & Dec-96 & & & & & Feb-97 & 11 & $\begin{array}{l}\text { Depositors' } \\
\text { funds in } \\
\text { licensed } \\
\text { deposit- } \\
\text { taking } \\
\text { institutions, } \\
\text { pension funds } \\
\text { managed by } \\
\text { authorized } \\
\text { institutions, } \\
\text { and policy- } \\
\text { holders funds } \\
\text { in insurance } \\
\text { companies } \\
\end{array}$ & $\mathrm{Y}$ & $\mathrm{Y}$ & 13.90 & \\
\hline
\end{tabular}




\begin{tabular}{|c|c|c|c|c|c|c|c|c|c|c|c|c|}
\hline \multirow[t]{2}{*}{ Country } & \multirow[t]{2}{*}{ Start 1/ } & \multicolumn{2}{|c|}{ Deposit Freeze } & \multicolumn{2}{|c|}{ Bank Holiday } & \multicolumn{3}{|c|}{ Guarantees on Bank Liabilities } & \multirow[t]{3}{*}{$\begin{array}{c}\text { Bank } \\
\text { Nationalization }\end{array}$} & \multirow[t]{3}{*}{$\begin{array}{c}\text { Asset } \\
\text { Purchase }\end{array}$} & \multirow{3}{*}{$\begin{array}{c}\text { Bank } \\
\text { Recapitalization } \\
\begin{array}{c}\text { In percent of } \\
\text { GDP }\end{array}\end{array}$} & \multirow[t]{2}{*}{$\begin{array}{c}\text { IMF } \\
\text { Program }\end{array}$} \\
\hline & & Date & Duration & Date & Duration & Start & Duration & Coverage & & & & \\
\hline & & & (in months) & & (in days) & & (in months) & & & & & \\
\hline Japan & Nov-97 & & & & & $\begin{array}{l}\text { Nov- } \\
97\end{array}$ & 89 & $\begin{array}{l}\text { All deposits, } \\
\text { including } \\
\text { interbank } \\
\text { deposits }\end{array}$ & $\mathrm{Y}$ & $\mathrm{Y}$ & 6.61 & \\
\hline Kazakhstan & Sep-08 & & & & & & & & $\mathrm{N}$ & $\mathrm{N}$ & 2.40 & \\
\hline Korea & Aug-97 & & & & & $\begin{array}{l}\text { Nov- } \\
97\end{array}$ & 37 & $\begin{array}{c}\text { All liabilities } \\
\text { (excluding } \\
\text { shareholders' } \\
\text { capital and } \\
\text { subordinated } \\
\text { debt) of } \\
\text { banks, } \\
\text { securities } \\
\text { companies, } \\
\text { insurance } \\
\text { companies, } \\
\text { merchant } \\
\text { banks, mutual } \\
\text { savings and } \\
\text { finance } \\
\text { companies, } \\
\text { and credit } \\
\text { unions. } \\
\text { Overseas } \\
\text { branches } \\
\text { were also } \\
\text { included. } \\
\end{array}$ & $\mathrm{Y}$ & $\mathrm{Y}$ & 19.31 & 1998 \\
\hline Latvia & Apr-95 & & & & & & & & $\mathrm{N}$ & $\mathrm{N}$ & 0.00 & 1993 \\
\hline Latvia & Sep-08 & 1-Dec-2008 & 6 & & & Dec-08 & & $\begin{array}{c}\text { Guarantees } \\
\text { on Parex } \\
\text { syndicated } \\
\text { loans } \\
\end{array}$ & $\mathrm{Y}$ & $\mathrm{N}$ & 3.10 & 2009 \\
\hline Lithuania & Dec-95 & & & & & & & & $\mathrm{Y}$ & $\mathrm{Y}$ & 1.70 & \\
\hline Luxembourg & Sep-08 & & & & & Oct-08 & & $\begin{array}{c}\text { Guarantees } \\
\text { on Dexia's } \\
\text { debt }\end{array}$ & $\mathrm{Y}$ & $\mathrm{N}$ & 7.70 & \\
\hline
\end{tabular}




\begin{tabular}{|c|c|c|c|c|c|c|c|c|c|c|c|c|}
\hline \multirow[t]{2}{*}{ Country } & \multirow[t]{2}{*}{ Start 1/ } & \multicolumn{2}{|c|}{ Deposit Freeze } & \multicolumn{2}{|c|}{ Bank Holiday } & \multicolumn{3}{|c|}{ Guarantees on Bank Liabilities } & \multirow[t]{3}{*}{$\begin{array}{c}\text { Bank } \\
\text { Nationalization }\end{array}$} & \multirow[t]{3}{*}{$\begin{array}{c}\text { Asset } \\
\text { Purchase }\end{array}$} & \multirow{3}{*}{$\begin{array}{c}\text { Bank } \\
\text { Recapitalization } \\
\begin{array}{c}\text { In percent of } \\
\text { GDP }\end{array}\end{array}$} & \multirow[t]{2}{*}{$\begin{array}{c}\text { IMF } \\
\text { Program }\end{array}$} \\
\hline & & Date & Duration & Date & Duration & Start & Duration & Coverage & & & & \\
\hline & & & (in months) & & (in days) & & (in months) & & & & & \\
\hline Malaysia & Jul-97 & & & & & Jan-98 & 91 & $\begin{array}{c}\text { Deposits only } \\
\text { of } \\
\text { commercial } \\
\text { banks, } \\
\text { finance } \\
\text { companies } \\
\text { and merchant } \\
\text { banks, } \\
\text { including } \\
\text { overseas } \\
\text { branches of } \\
\text { domestic } \\
\text { banking } \\
\text { institutions. }\end{array}$ & $\mathrm{Y}$ & $\mathrm{Y}$ & 16.40 & \\
\hline Mexico & Dec-94 & & & & & Dec-93 & 109 & $\begin{array}{c}\text { All bank } \\
\text { liabilities } \\
\text { except } \\
\text { subordinated } \\
\text { debt }\end{array}$ & $\mathrm{Y}$ & $\mathrm{Y}$ & 3.80 & 1995 \\
\hline Moldova & Nov-14 & & & & & & & & $\mathrm{N}$ & $\mathrm{N}$ & 0.00 & \\
\hline Mongolia & Sep-08 & & & & & & & $\begin{array}{l}\text { Unlimited } \\
\text { coverage to } \\
\text { all deposits. }\end{array}$ & $\mathrm{Y}$ & $\mathrm{N}$ & 4.20 & 2009 \\
\hline Netherlands & Sep-08 & & & & & Oct-08 & & $\begin{array}{c}\text { Interbank } \\
\text { loans of } \\
\text { solvent } \\
\text { banks. }\end{array}$ & $\mathrm{Y}$ & $\mathrm{N}$ & 6.30 & \\
\hline Nicaragua & Aug-00 & & & & & Jan-01 & 14 & $\begin{array}{l}\text { All deposit } \\
\text { liabilities } \\
\text { except for } \\
\text { related } \\
\text { parties. }\end{array}$ & $\mathrm{N}$ & $\mathrm{Y}$ & 0.00 & \\
\hline Nigeria & Aug-09 & & & & & Oct-09 & & $\begin{array}{c}\text { Guarantees } \\
\text { on all } \\
\text { interbank } \\
\text { transactions, } \\
\text { foreign credit } \\
\text { lines and } \\
\text { pension } \\
\text { deposits. } \\
\end{array}$ & $\bar{Y}$ & $\mathrm{Y}$ & 11.80 & \\
\hline
\end{tabular}




\begin{tabular}{|c|c|c|c|c|c|c|c|c|c|c|c|c|}
\hline \multirow[t]{3}{*}{ Country } & \multirow[t]{3}{*}{ Start 1/ } & \multicolumn{2}{|c|}{ Deposit Freeze } & \multicolumn{2}{|c|}{ Bank Holiday } & \multicolumn{3}{|c|}{ Guarantees on Bank Liabilities } & \multirow[t]{3}{*}{$\begin{array}{c}\text { Bank } \\
\text { Nationalization }\end{array}$} & \multirow[t]{3}{*}{$\begin{array}{c}\text { Asset } \\
\text { Purchase }\end{array}$} & \multirow{3}{*}{$\begin{array}{c}\text { Bank } \\
\text { Recapitalization } \\
\begin{array}{c}\text { In percent of } \\
\text { GDP }\end{array}\end{array}$} & \multirow[t]{2}{*}{$\begin{array}{c}\text { IMF } \\
\text { Program }\end{array}$} \\
\hline & & Date & Duration & Date & Duration & Start & Duration & Coverage & & & & \\
\hline & & & (in months) & & (in days) & & (in months) & & & & & \\
\hline Norway & Oct-91 & & & & & & & & $\mathrm{Y}$ & $\mathrm{N}$ & 2.61 & \\
\hline Paraguay & May-95 & & & & & Jul-95 & 11 & $\begin{array}{l}\text { Announceme } \\
\text { nt included } \\
\text { backing of all } \\
\text { deposits, but } \\
\text { no explicit } \\
\text { breakdown } \\
\text { was given. }\end{array}$ & $\mathrm{N}$ & $\mathrm{N}$ & 1.22 & \\
\hline Philippines & Jul-97 & & & & & & & & $\mathrm{N}$ & $\mathrm{N}$ & 0.20 & 1998 \\
\hline Portugal & Sep-08 & & & & & Oct-08 & & $\begin{array}{c}\text { Debt issued } \\
\text { by credit } \\
\text { institutions. }\end{array}$ & $\mathrm{N}$ & $\mathrm{N}$ & 0.00 & 2011 \\
\hline Russia & Aug-98 & & & & & & & & $\mathrm{Y}$ & $\mathrm{Y}$ & 0.00 & 1999 \\
\hline Russia & Sep-08 & & & & & $\begin{array}{c}\text { Nov- } \\
08\end{array}$ & & $\begin{array}{c}\text { Interbank } \\
\text { borrowing for } \\
\text { qualifying } \\
\text { banks. }\end{array}$ & $\mathrm{N}$ & $\mathrm{N}$ & 2.30 & \\
\hline Slovenia & Sep-08 & & & & & Dec-08 & & $\begin{array}{c}\text { Unlimited } \\
\text { protection for } \\
\text { all deposits } \\
\text { by } \\
\text { individuals } \\
\text { and small } \\
\text { enterprises } \\
\text { until end- } \\
2010 \text {, and } \\
\text { capped at } \\
€ 100,000 \\
\text { thereafter } \\
\end{array}$ & $\mathrm{N}$ & $\mathrm{N}$ & 0.80 & \\
\hline Spain & Sep-08 & & & & & Oct- 08 & & & $\mathrm{~N}$ & $\mathrm{Y}$ & 2.00 & \\
\hline Sri Lanka & Jun-05 & & & & & & & & $\mathrm{N}$ & $\mathrm{N}$ & 3.60 & \\
\hline Sweden & Sep-91 & & & & & Sep-92 & 46 & $\begin{array}{c}\text { All liabilities, } \\
\text { except for } \\
\text { shareholders } \\
\end{array}$ & $\mathrm{Y}$ & $\mathrm{Y}$ & 1.85 & \\
\hline Sweden & Sep-08 & & & & & Oct- 08 & & $\begin{array}{l}\text { Medium-term } \\
\text { debt of banks } \\
\text { and mortgage } \\
\text { institutions }\end{array}$ & $\mathrm{N}$ & $\mathrm{N}$ & 0.20 & \\
\hline
\end{tabular}




\begin{tabular}{|c|c|c|c|c|c|c|c|c|c|c|c|c|}
\hline \multirow[t]{2}{*}{ Country } & \multirow[t]{2}{*}{ Start 1/ } & \multicolumn{2}{|c|}{ Deposit Freeze } & \multicolumn{2}{|c|}{ Bank Holiday } & \multicolumn{3}{|c|}{ Guarantees on Bank Liabilities } & \multirow[t]{3}{*}{$\begin{array}{c}\text { Bank } \\
\text { Nationalization }\end{array}$} & \multirow[t]{3}{*}{$\begin{array}{c}\text { Asset } \\
\text { Purchase }\end{array}$} & \multirow{3}{*}{$\begin{array}{c}\text { Bank } \\
\text { Recapitalization } \\
\begin{array}{c}\text { In percent of } \\
\text { GDP }\end{array}\end{array}$} & \multirow[t]{2}{*}{$\begin{array}{c}\text { IMF } \\
\text { Program }\end{array}$} \\
\hline & & Date & Duration & Date & Duration & Start & Duration & Coverage & & & & \\
\hline & & & (in months) & & (in days) & & (in months) & & & & & \\
\hline Switzerland & Sep-08 & & & & & & & & $\mathrm{N}$ & $\mathrm{Y}$ & 1.10 & \\
\hline Thailand & Jul-97 & & & & & $\begin{array}{l}\text { Aug- } \\
97\end{array}$ & 89 & $\begin{array}{c}\text { Deposits, } \\
\text { contingent } \\
\text { and foreign } \\
\text { liabilities } \\
\text { (excluding } \\
\text { shareholders' } \\
\text { capital and } \\
\text { subordinated } \\
\text { debt) of } \\
\text { banks and } \\
\text { finance } \\
\text { companies. } \\
\text { Directors' } \\
\text { and related } \\
\text { persons' } \\
\text { deposits } \\
\text { and/or claims } \\
\text { were not } \\
\text { covered } \\
\text { unless it } \\
\text { could be } \\
\text { proven that } \\
\text { the } \\
\text { transactions } \\
\text { were at arms' } \\
\text { length. }\end{array}$ & $\bar{Y}$ & $\bar{Y}$ & 18.80 & 1998 \\
\hline Turkey & Nov-00 & & & & & Dec-00 & 43 & $\begin{array}{l}\text { All liabilities } \\
\text { (including } \\
\text { contingent) of } \\
\text { domestically } \\
\text { incorporated } \\
\text { banks except } \\
\text { for owners' } \\
\text { deposits, } \\
\text { deposits } \\
\text { linked to } \\
\text { criminal } \\
\text { activities, } \\
\text { subordinated }\end{array}$ & $\mathrm{Y}$ & $\mathrm{Y}$ & 24.50 & 2000 \\
\hline
\end{tabular}




\begin{tabular}{|c|c|c|c|c|c|c|c|c|c|c|c|c|}
\hline \multirow[t]{2}{*}{ Country } & \multirow[t]{2}{*}{ Start 1/ } & \multicolumn{2}{|c|}{ Deposit Freeze } & \multicolumn{2}{|c|}{ Bank Holiday } & \multicolumn{3}{|c|}{ Guarantees on Bank Liabilities } & \multirow[t]{3}{*}{$\begin{array}{c}\text { Bank } \\
\text { Nationalization }\end{array}$} & \multirow[t]{3}{*}{$\begin{array}{c}\text { Asset } \\
\text { Purchase }\end{array}$} & \multirow{3}{*}{$\begin{array}{c}\text { Bank } \\
\text { Recapitalization } \\
\text { In percent of } \\
\text { GDP }\end{array}$} & \multirow[t]{2}{*}{$\begin{array}{c}\text { IMF } \\
\text { Program }\end{array}$} \\
\hline & & Date & Duration & Date & Duration & Start & Duration & Coverage & & & & \\
\hline & & & (in months) & & (in days) & & (in months) & & & & & \\
\hline & & & & & & & & $\begin{array}{c}\text { debt, and } \\
\text { equity }\end{array}$ & & & & \\
\hline Ukraine & Aug-98 & & & & & & & & $\mathrm{N}$ & $\mathrm{N}$ & 0.00 & 1995 \\
\hline Ukraine & Sep-08 & & & & & & & & $\mathrm{Y}$ & $\mathrm{N}$ & 4.50 & $\begin{array}{l}2009, \\
2010\end{array}$ \\
\hline Ukraine & Feb-14 & 1-Mar-2014 & 40 & & & & & & $\mathrm{Y}$ & $\mathrm{N}$ & 7.20 & 2014 \\
\hline $\begin{array}{l}\text { United } \\
\text { Kingdom }\end{array}$ & Sep-07 & & & & & Oct-08 & & $\begin{array}{c}\text { Guarantee on } \\
\text { short-to- } \\
\text { medium term } \\
\text { debt; blanket } \\
\text { guarantee on } \\
\text { Northern } \\
\text { Rock and } \\
\text { Bradford \& } \\
\text { Bingley } \\
\text { wholesale } \\
\text { deposits. }\end{array}$ & $\mathrm{Y}$ & $\mathrm{Y}$ & 5.00 & \\
\hline United States & Dec-07 & & & & & Oct-08 & & $\begin{array}{c}\text { Money } \\
\text { market funds } \\
\text { (capped at } \\
\text { US\$50 } \\
\text { billion); full } \\
\text { guarantee on } \\
\text { transaction } \\
\text { deposits; } \\
\text { newly issued } \\
\text { senior } \\
\text { unsecured } \\
\text { debt. }\end{array}$ & $\mathrm{Y}$ & $\mathrm{Y}$ & 3.60 & \\
\hline Uruguay & Jan-02 & 5-Aug-2002 & 36 & 30-Apr-2002 & 5 & & & & $\mathrm{Y}$ & $\mathrm{Y}$ & 6.18 & 1996 \\
\hline Venezuela & Jan-94 & & & & & & & & $\mathrm{Y}$ & $\mathrm{N}$ & 5.59 & 1996 \\
\hline Vietnam & Nov-97 & & & & & & & & $\mathrm{N}$ & $\mathrm{Y}$ & 5.00 & \\
\hline
\end{tabular}




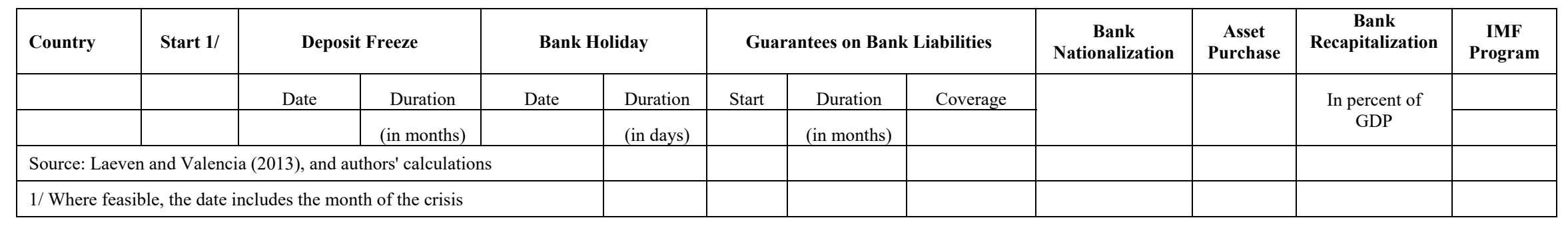

